\title{
Hydrochemical Characteristics and Water Quality of Groundwater in the Thick Loess Deposits
}

\section{Shujian Li}

Northwest Agriculture and Forestry University College of Resources and Environment

He Su ( $\nabla$ suhe@tyut.edu.cn )

Taiyuan University of Technology https://orcid.org/0000-0001-5752-2369

Zhi Li

Northwest Agriculture and Forestry University College of Resources and Environment

\section{Research Article}

Keywords: Arid climate, Thick vadose zones, Hydrochemistry, Hierarchical cluster analysis, Solute sources, Chinese Loess Plateau

Posted Date: February 5th, 2021

DOI: https://doi.org/10.21203/rs.3.rs-172765/v1

License: @ (i) This work is licensed under a Creative Commons Attribution 4.0 International License. Read Full License 


\title{
1 Hydrochemical characteristics and water quality of groundwater
}

\section{2 in the thick loess deposits}

\author{
3 \\ Shujian $\mathrm{Li}^{1}, \mathrm{He} \mathrm{Su}^{2}$, Zhi $\mathrm{Li}^{1}$ \\ $4{ }^{1}$ College of Natural Resources and Environment, Northwest A\&F University, Yangling, Shaanxi, \\ 5712100, China \\ $6 \quad{ }^{2}$ College of Mining Engineering, Taiyuan University of Technology, Taiyuan, Shanxi, 030024, \\ 7 China \\ 8 Correspondence to Zhi Li (Email: lizhibox@nwafu.edu.cn) and He Su (Email: \\ 9 suhe@tyut.edu.cn).
}

10

11

12

13

14

15

16

17

18

19 
Abstract: Water quality and quantity should be paid more attentions for regions with arid climate and thick vadose zones since the limited groundwater cannot be replenished rapidly once polluted. This study focused on the Loess Plateau of China to investigate the geochemical mechanism affecting groundwater chemistry and to calculate contribution rates of multiple sources to groundwater solutes. We employed multiple methods (diagrams, bivariate analyses, hierarchical cluster analysis (HCA), sodium adsorption ratio (SAR), water quality index (WQI), correlation analysis, forward simulation) for the above purposes. We collected 64 groundwater samples in the thick loess deposits in June 2018 (flood season) and April 2019 (dry season). The average concentrations of cation were in the order of $\mathrm{Ca}^{2+}>\mathrm{Na}^{+}>\mathrm{Mg}^{2+}>\mathrm{K}^{+}$in the flood season, and $\mathrm{Na}^{+}>\mathrm{Ca}^{2+}>\mathrm{Mg}^{2+}>\mathrm{K}^{+}$in the dry season. The order of anions contents in the flood season and the dry season was $\mathrm{HCO}_{3}{ }^{-}>\mathrm{SO}_{4}{ }^{2-}>\mathrm{Cl}^{-}>\mathrm{NO}_{3}{ }^{-}$. The major hydrochemical facies were $\mathrm{Ca}-\mathrm{HCO}_{3}$ and $\mathrm{Ca} \cdot \mathrm{Mg}-\mathrm{HCO}_{3}$ in the flood season, and $\mathrm{Na} \cdot \mathrm{Ca}-\mathrm{HCO}_{3} \cdot \mathrm{SO}_{4}$ and $\mathrm{Na}-\mathrm{HCO}_{3}$ in the dry season, respectively. Most of the groundwater (95\% in the flood season and $96 \%$ in the dry season) was suitable for drinking, and overall water quality (except samples F28 and D13) was acceptable for irrigation. Mineral dissolution and cation exchange were important natural processes affecting groundwater chemistry. A forward model showed that the contribution of atmospheric input, anthropogenic input, evaporite dissolution, silicate weathering and carbonate weathering to solutes in groundwater was $2.3 \pm 1.5 \%, 5.0 \pm 7.1 \%, 19.3 \pm 21.4 \%$, $42.8 \pm 27.3 \%$ and $30.6 \pm 27.1 \%$ in the flood season, and $9.1 \pm 6.4 \%, 3.4 \pm 5.2 \%, 20.3 \pm 15.9$, $56.6 \pm 23.2 \%$, and $10.7 \pm 15.4 \%$ in the dry season, respectively. Although the overall contribution of anthropogenic inputs was minor, it was the dominant source of solutes for some groundwater samples. This study provides fundamental information for water management in arid areas.

Keywords: Arid climate; Thick vadose zones; Hydrochemistry; Hierarchical cluster 46 


\section{Introduction}

Groundwater in arid regions is crucial to support sustainable socio-economic development since they are the only available and stable water sources with large reserves (Li et al. 2016, 2019a; Aghababazadeh et al. 2016; Wang et al. 2017). However, groundwater is currently severely threatened by excessive extraction and pollution (Brindha et al. 2011; Alarcon-Herrera et al. 2013; Subba Rao 2020). The growing demand for water resources leads to the excessive groundwater extraction (López-Alvis et al. 2019; Subba Rao et al. 2020). Simultaneously, the deterioration of water quality indirectly reduces the available groundwater amount (Wu and Sun 2016; Brindha et al. 2016; Li et al. 2017a). Particularly, water pollution treatment is hardly to be conducted for groundwater, which extends the risk of contaminated groundwater (Liu et al. 2018). In consequence, the scarcity of groundwater in arid regions caused by the arid climate and water pollution has been paid increasing attentions.

Groundwater, especially those stored in deep aquifers, should be of high priority for protection. These groundwater resources generally have large reserves sustaining regional development, but they have slow renewal rate and are difficult to be replenished. However, the global-scale analysis showed that the water storage of several major aquifers in arid mid-latitudes have declined severely from 2002 to 2013 (Famiglietti 2014), and contemporary pollutants may be able to reach deep aquifers (Jasechko et al. 2017). As such, it is fundamental to investigate the changes in quantity and quality of groundwater resources in regions with deep vadose zones and aquifers.

Investigating the hydrogeochemical characteristic is the prerequisite for the analysis of water quality and potential pollution sources (Ahada et al. 2013). However, the hydrochemical characteristics of groundwater are affected by both the long-term geological evolution and immediate anthropogenic activities (Yong-Hong et al. 2007). 
72 With such complicated sources and processes, the hydrochemical characteristics and 73 water quality may vary spatially and temporally. For example, López-Alvis et al. (2019)

74 discovered that the groundwater quality of Siwa Oasis in Egypt had been deteriorating in alarming rate over the past 11 years due to unsafe groundwater extraction from deep sandstone aquifers. Zanotti et al. (2019) reflected the significant spatial difference in groundwater quality between the higher and lower plains of Oglio River basin. Xiao et al. (2015) found that the concentrations of ions in groundwater of the Tarim River Basin varied significantly with a higher concentration in the dry season than in the wet season. The spatiotemporal variations in groundwater hydrochemcial characteristics highlights the importance of dynamic sampling on a large spatial scale to provide detailed information for water resources management.

The Loess Plateau in China is the largest area covered by loess deposit up to $350 \mathrm{~m}$ deep (Zhu et al. 2018). The thick loess stores huge groundwater reservoirs, which dominates the watershed-scale hydrological processes ( $\mathrm{Li}$ et al. 2019b). The groundwater recharge mechanism and the groundwater depletion has been widely reported (Huang et al. 2018). However, the hydrochemical characteristics and water quality have not been fully investigated. For example, Li et al. (2014) assessed the shallow groundwater in the Zhongwei section of the Loess Plateau, and concluded that the excessive $\mathrm{Cl}^{-}$and $\mathrm{SO}_{4}{ }^{2-}$ made groundwater in most areas unsuitable for direct human consumption. Although groundwater quality evaluation based on a single sampling (Yu et al. 2020) has been conducted for some limited regions, it cannot represent the hydrochemical characteristics on a large scale considering seasonality. As such, groundwater quality investigation considering the spatial and temporal variability in this region can provide valuable information for other regions with thick vadose zones and aquifers.

The objective of this research is to investigate the hydrochemical characteristics and 
assess the groundwater quality in the Loess Plateau. In specific, we will ask the following questions: (1) What are the hydrochemical characteristics and quality of groundwater in the thick loess? (2) Why do the hydrochemical characteristics and water quality vary spatiotemporally? (3) What processes are driving the hydrochemical characteristics? To answer the above questions, we launched two groundwater sampling campaigns across the whole loess-covered regions considering the seasonality. After determining the ion contents, we analyzed the general characteristics, hydrochemical facies and water quality for drinking and irrigation purpose. Our results will be helpful for groundwater management in other loess-covered regions or other region with thick vadose zones and aquifers.

\section{Materials and Methods}

\subsection{Study area}

The Loess Plateau in north China (Fig. 1) is the largest loess-covered area in the world (Xiao 2016). It extends from the Riyue and Helan Mountains in the west to the Taihang Mountains in the east, from the Yinshan Mountains in the north to the Qinling Mountains in the south, covering an area of approximately $64 \times 10^{5} \mathrm{~km}^{2}$. The area spans a semiarid to subhumid climate from west to east, with a mean annual temperature of $14.3^{\circ} \mathrm{C}$ in the east and $4.3^{\circ} \mathrm{C}$ in the west. The mean annual precipitation varies from 150 $\mathrm{mm}$ in the west to $800 \mathrm{~mm}$ in the east, and most of the rainfall is concentrated from June to September (Li et al. 2010). Generally, the Quaternary loess is layered deposits consisted of Wucheng loess $\left(\mathrm{Q}_{1}\right)$, Lishi loess $\left(\mathrm{Q}_{2}\right)$ and Malan loess $\left(\mathrm{Q}_{3}\right)$ from bottom to top. The Wucheng loess has low permeability, the Lishi loess is considered to be a good aquifer due to the relatively large porosity, and the Malan loess is the top soil (Huang et al. 2017). However, due to the severe soil erosion, the thickness of loess and the topography vary greatly in space, which has a great impact on the water level and reserves of groundwater (Gates et al. 2011). 
124 As the most common minerals in carbonates and Quaternary sediments, calcite, 125 dolomite, feldspar, gypsum, and halide provide abundant soluble components for 126 groundwater (Xiao 2016). Moreover, human activities may also have a certain impact 127 on quality of groundwater. As a traditional agricultural area and an important national 128 energy base, the incidents of groundwater pollution in the Loess Plateau by industrial 129 sewage and agricultural activities have been widely reported (Li 2018; Huang et al. 130 2018). 


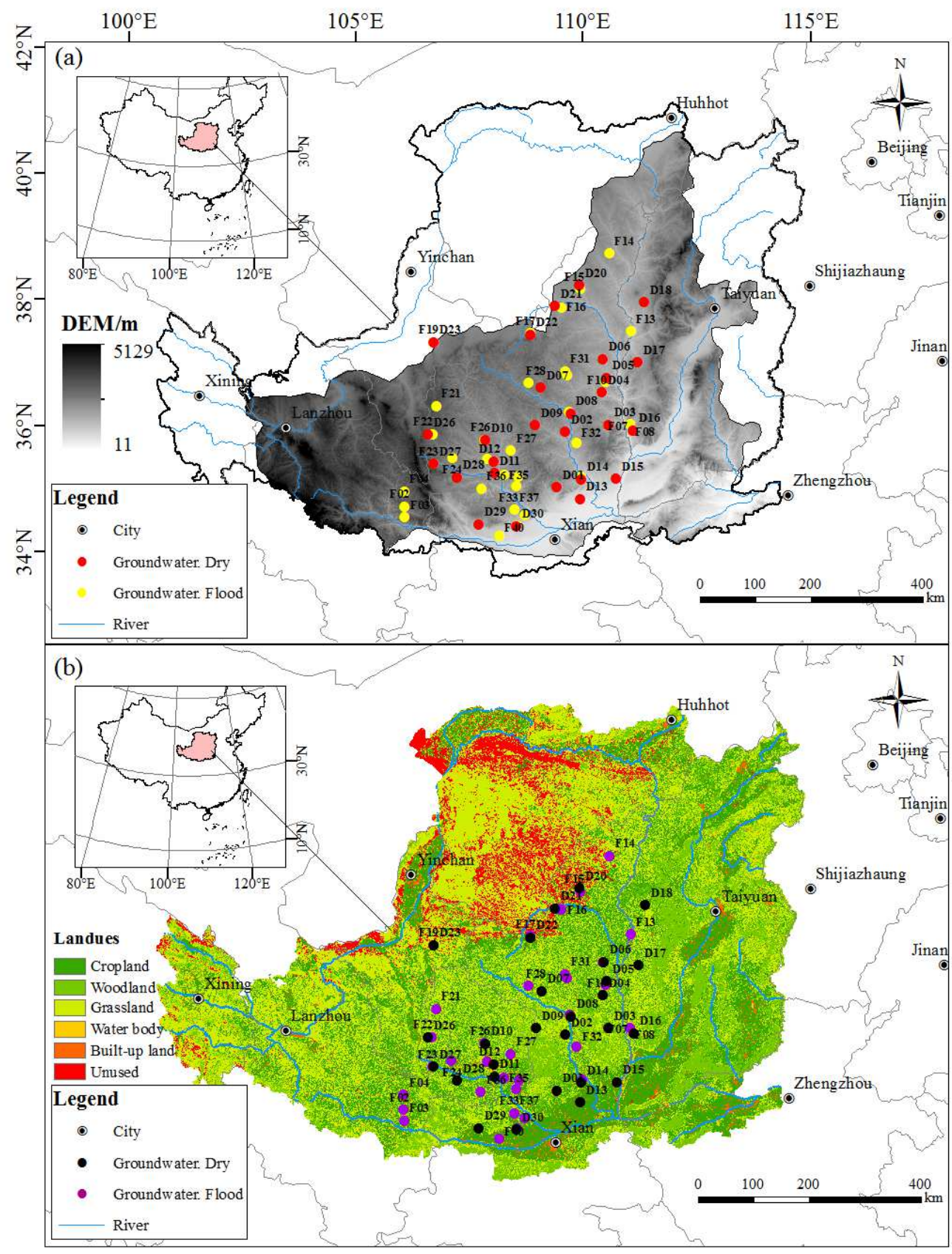

132 Fig. 1 (a) Geographical location of the Loess Plateau and groundwater sampling sites. (b) Land use 133 of the Loess Plateau.

\section{$134 \quad 2.2$ Sample collection and analysis}

135 In this study, we focused on the unconfined groundwater that discharges into rivers

136 instead of getting recharge from rivers. The above-mentioned groundwater is generally

137 stored in high-altitudes areas where surface water is scarce and groundwater become 
138 the only water source. The groundwater level in these areas is generally $10 \mathrm{~m}$ below the 139 ground surface. These groundwater samples exclude the impacts of surface water, thus 140 highlighting the impacts of anthropogenic activities.

141 We collected 64 groundwater samples in the thick loess deposits, among which 37 142 samples were collected during the flood season (August 2018) and 27 samples from the 143 dry season (April 2019). In order to eliminate the negative effects of stagnant water, the 144 wells were pumped for at least 10 minutes before sampling. All groundwater samples 145 were stored in plastic bottles and kept in a portable fridge. The samples were delivered 146 back to the laboratory by fast delivery at the end of each day to ensure that the 147 hydrochemical components can be determined in the next day. The temperature, $\mathrm{pH}$, 148 total dissolved solids (TDS), electrical conductivity (EC) were measured by a portable 149 meter (HANNA, HI98130) in situ. Major cations $\left(\mathrm{K}^{+}, \mathrm{Na}^{+}, \mathrm{Ca}^{+}\right.$, and $\left.\mathrm{Mg}^{+}\right)$were 150 determined by a coupled plasma-atomic emission spectrometry. $\mathrm{Cl}^{-}, \mathrm{SO}_{4}{ }^{2-}$, and $\mathrm{NO}_{3}{ }^{-}$ 151 were determined by ion chromatography (DIONEX ICS-1100, Thermal Fisher

152 Scientific, USA). The $\mathrm{HCO}_{3}{ }^{-}$content was measured by titration with hydrochloric acid 153 (Table 1).

154 Table 1 Chemical composition of groundwater samples and water quality assessment results for 155 irrigation and drinking purposes in the study area.

\begin{tabular}{|c|c|c|c|c|c|c|c|c|c|c|c|c|c|c|c|c|c|}
\hline \multirow{2}{*}{$\begin{array}{c}\text { Sample } \\
\text { No. }\end{array}$} & \multirow{2}{*}{ Group } & \multirow{2}{*}{$\begin{array}{l}\text { Well } \\
\text { depth } \\
\text { (m) }\end{array}$} & \multirow{2}{*}{ Landuse } & \multirow{2}{*}{$\mathrm{pH}$} & \multirow{2}{*}{$\begin{array}{c}\mathrm{EC} \\
(\mu \mathrm{S} / \mathrm{cm})\end{array}$} & \multirow{2}{*}{$\begin{array}{c}\text { TDS } \\
\left(\mathrm{mg} \cdot \mathrm{L}^{-1}\right)\end{array}$} & \multicolumn{8}{|c|}{ Ion concentration $\left(\mathrm{mg} \cdot \mathrm{L}^{-1}\right)$} & \multicolumn{3}{|c|}{ Quality assessment } \\
\hline & & & & & & & $\mathrm{Ca}^{2+}$ & $\mathrm{Mg}^{2+}$ & $\mathrm{Na}^{+}$ & $\mathrm{K}^{+}$ & $\mathrm{HCO}_{3}^{-}$ & $\mathrm{SO}_{4}^{2-}$ & $\mathrm{NO}_{3}^{-}$ & $\mathrm{Cl}^{-}$ & SAR & $\% \mathrm{Na}$ & WQI \\
\hline \multicolumn{18}{|c|}{ Flood Season } \\
\hline F28 & F-Group 1 & 11 & Cropland & 6.84 & 2848 & 1410 & 168.57 & 69.76 & 226.42 & 3.83 & 476.41 & 177.99 & 63.58 & 461.09 & 1.97 & 24.79 & 122.11 \\
\hline F30 & F-Group 1 & 18 & Built-up land & 6.66 & 1795 & 978 & 238.71 & 79.06 & 137.95 & 4.15 & 851.69 & 168.22 & 165.93 & 159.21 & 3.69 & 41.11 & 131.87 \\
\hline F11 & F-Group 2 & - & Cropland & 7.32 & 1663 & 834 & 66.72 & 33.54 & 49.02 & 2.08 & 322.15 & 68.70 & 22.28 & 44.14 & 0.14 & 4.19 & 56.52 \\
\hline F12 & F-Group 2 & 23 & Cropland & 7.48 & 1100 & 550 & 31.37 & 24.54 & 70.85 & 1.40 & 263.72 & 86.45 & 9.38 & 16.13 & 0.30 & 6.87 & 36.17 \\
\hline F15 & F-Group 2 & 50 & Grassland & 7.02 & 736 & 371 & 149.39 & 10.65 & 6.53 & 3.17 & 410.51 & 88.22 & 1.95 & 4.35 & 0.33 & 9.68 & 18.13 \\
\hline F16 & F-Group 2 & 12 & Built-up land & 7.54 & 867 & 433 & 116.28 & 19.88 & 56.35 & 2.08 & 484.22 & 43.18 & 42.02 & 16.27 & 0.37 & 8.11 & 31.56 \\
\hline F17 & F-Group 2 & 15 & Cropland & 7.57 & 890 & 477 & 105.87 & 35.05 & 24.25 & 3.02 & 456.90 & 12.76 & 73.75 & 14.21 & 0.37 & 15.88 & 41.80 \\
\hline F19 & F-Group 2 & 19 & Grassland & 7.50 & 1967 & 953 & 105.53 & 19.83 & 144.00 & 1.97 & 490.57 & 141.45 & 3.27 & 78.05 & 0.38 & 10.58 & 28.71 \\
\hline
\end{tabular}




\begin{tabular}{|c|c|c|c|c|c|c|c|c|c|c|c|c|c|c|c|c|c|}
\hline $\mathrm{F} 2$ & F-Group 2 & - & Cropland & 7.30 & 771 & 385 & 159.26 & 26.05 & 15.30 & 3.21 & 212.85 & 166.68 & 26.84 & 123.77 & 0.38 & 9.29 & 33.84 \\
\hline F25 & F-Group 2 & 80 & Built-up land & 7.54 & 608 & 303 & 73.59 & 29.08 & 18.70 & 1.63 & 395.30 & 6.82 & 10.99 & 5.62 & 0.45 & 14.33 & 43.66 \\
\hline F27 & F-Group 2 & 180 & Cropland & 7.01 & 566 & 284 & 78.52 & 24.30 & 15.08 & 1.89 & 371.09 & 10.79 & 13.58 & 4.56 & 0.45 & 13.62 & 50.93 \\
\hline F29 & F-Group 2 & 20 & Grassland & 6.83 & 1123 & 566 & 79.21 & 38.25 & 89.75 & 12.62 & 558.77 & 50.31 & 8.53 & 36.49 & 0.47 & 12.29 & 53.31 \\
\hline F3 & F-Group 2 & - & Built-up land & 7.86 & 1250 & 647 & 22.88 & 15.89 & 136.16 & 2.42 & 347.09 & 102.32 & 12.35 & 34.90 & 0.52 & 12.11 & 22.63 \\
\hline F31 & F-Group 2 & 210 & Cropland & 7.46 & 595 & 298 & 72.40 & 21.47 & 20.66 & 2.27 & 344.51 & 13.58 & 12.97 & 8.01 & 0.55 & 15.02 & 23.47 \\
\hline F32 & F-Group 2 & 80 & Built-up land & 8.20 & 539 & 270 & 74.56 & 21.09 & 12.52 & 1.70 & 341.25 & 6.96 & 10.15 & 6.04 & 0.65 & 16.32 & 45.95 \\
\hline F33 & F-Group 2 & 70 & Built-up land & 8.30 & 593 & 294 & 139.69 & 31.07 & 18.55 & 1.49 & 591.66 & 13.27 & 15.58 & 6.79 & 0.87 & 16.91 & 23.56 \\
\hline F34 & F-Group 2 & 120 & Built-up land & 8.33 & 613 & 306 & 131.23 & 24.89 & 18.34 & 3.38 & 560.59 & 5.85 & 5.28 & 4.35 & 1.22 & 26.27 & 21.00 \\
\hline F35 & F-Group 2 & 60 & Built-up land & 8.41 & 657 & 328 & 47.95 & 18.09 & 75.16 & 5.46 & 418.30 & 2.73 & 16.61 & 4.62 & 1.27 & 25.10 & 32.30 \\
\hline F36 & F-Group 2 & 6 & Cropland & 8.12 & 525 & 262 & 76.77 & 5.08 & 12.45 & 10.25 & 284.72 & 13.53 & 1.53 & 3.24 & 2.06 & 37.16 & 28.91 \\
\hline F37 & F-Group 2 & - & Built-up land & 8.49 & 702 & 351 & 78.17 & 16.54 & 17.01 & 3.67 & 342.53 & 5.17 & 11.18 & 7.71 & 2.29 & 46.30 & 27.15 \\
\hline F38 & F-Group 2 & - & Built-up land & 8.63 & 781 & 391 & 40.36 & 27.01 & 82.68 & 3.45 & 423.00 & 19.46 & 20.92 & 9.76 & 2.34 & 46.60 & 25.04 \\
\hline F39 & F-Group 2 & 40 & Built-up land & 8.58 & 751 & 375 & 48.34 & 49.86 & 122.58 & 1.95 & 555.22 & 72.18 & 32.60 & 29.10 & 2.46 & 46.31 & 24.58 \\
\hline F40 & F-Group 2 & 180 & Built-up land & 8.52 & 721 & 360 & 143.26 & 29.88 & 44.08 & 1.85 & 672.33 & 5.12 & 20.79 & 5.42 & 2.94 & 45.01 & 29.23 \\
\hline F5 & F-Group 2 & 40 & Built-up land & 7.84 & 495 & 247 & 62.44 & 15.82 & 15.28 & 3.05 & 320.25 & 3.10 & 5.34 & 0.98 & 3.36 & 47.67 & 40.87 \\
\hline F9 & F-Group 2 & 5 & Grassland & 7.69 & 847 & 423 & 111.97 & 15.96 & 27.70 & 5.72 & 468.34 & 9.37 & 7.94 & 9.88 & 5.33 & 70.79 & 36.46 \\
\hline $\mathrm{F} 1$ & F-Group 3 & - & Grassland & 7.60 & 510 & 255 & 48.28 & 10.43 & 10.78 & 1.76 & 190.46 & 23.29 & 4.19 & 4.34 & 0.21 & 7.99 & 15.71 \\
\hline F10 & F-Group 3 & - & Grassland & 7.35 & 825 & 413 & 26.09 & 10.30 & 45.63 & 3.33 & 205.66 & 28.74 & 3.38 & 7.36 & 0.22 & 12.80 & 13.35 \\
\hline F13 & F-Group 3 & - & Grassland & 7.40 & 640 & 320 & 39.09 & 16.08 & 26.88 & 1.21 & 135.87 & 60.37 & 6.12 & 32.32 & 0.37 & 13.53 & 11.85 \\
\hline F14 & F-Group 3 & 14 & Cropland & 7.49 & 790 & 392 & 79.58 & 12.73 & 7.79 & 3.86 & 178.12 & 17.86 & 132.97 & 5.93 & 0.39 & 16.12 & 23.09 \\
\hline F21 & F-Group 3 & 11 & Cropland & 7.74 & 1130 & 565 & 23.48 & 11.70 & 129.74 & 3.27 & 140.34 & 50.42 & 100.24 & 103.17 & 0.84 & 26.45 & 19.17 \\
\hline F22 & F-Group 3 & 45 & Grassland & 7.50 & 903 & 482 & 26.33 & 21.05 & 23.96 & 2.44 & 176.47 & 33.56 & 14.95 & 12.13 & 0.91 & 26.69 & 21.04 \\
\hline F23 & F-Group 3 & - & Grassland & 7.23 & 663 & 333 & 42.00 & 13.43 & 11.37 & 4.85 & 181.48 & 11.16 & 21.24 & 10.20 & 0.97 & 35.09 & 61.84 \\
\hline F24 & F-Group 3 & 130 & Cropland & 7.27 & 616 & 308 & 27.38 & 10.61 & 36.09 & 1.54 & 208.42 & 8.94 & 8.87 & 4.11 & 1.48 & 41.66 & 62.37 \\
\hline F26 & F-Group 3 & 150 & Cropland & 7.05 & 529 & 265 & 47.65 & 15.45 & 51.49 & 1.81 & 335.84 & 3.37 & 15.40 & 4.64 & 1.65 & 38.37 & 23.15 \\
\hline F4 & F-Group 3 & - & Cropland & 7.66 & 831 & 415 & 18.46 & 9.23 & 20.42 & 1.04 & 140.25 & 6.82 & 4.37 & 3.36 & 1.91 & 48.89 & 23.95 \\
\hline F7 & F-Group 3 & - & Grassland & 7.60 & 417 & 453 & 19.08 & 5.58 & 4.17 & 1.04 & 88.62 & 3.33 & 2.46 & 2.30 & 2.23 & 50.14 & 15.86 \\
\hline F8 & F-Group 3 & - & Grassland & 7.95 & 705 & 350 & 21.15 & 17.82 & 57.79 & 1.75 & 219.98 & 24.58 & 19.17 & 23.88 & 5.44 & 72.70 & 20.90 \\
\hline \multicolumn{18}{|c|}{ Dry Season } \\
\hline D13 & D-Group 1 & 75 & Cropland & 7.51 & 2030 & 1015 & 33.13 & 61.67 & 1213.50 & 2.03 & 2960.39 & 316.35 & 78.50 & 114.35 & 28.62 & 88.60 & 148.78 \\
\hline D1 & D-Group 2 & 5 & Grassland & 7.22 & 840 & 420 & 116.01 & 31.80 & 37.87 & 2.35 & 342.70 & 176.31 & 11.72 & 24.03 & 0.16 & 5.10 & 43.00 \\
\hline D12 & D-Group 2 & 32 & Cropland & 7.32 & 560 & 280 & 36.92 & 35.21 & 20.18 & 1.89 & 284.00 & 13.95 & 25.71 & 12.26 & 0.49 & 12.99 & 29.11 \\
\hline D17 & D-Group 2 & 52 & Grassland & 7.74 & 1220 & 610 & 62.52 & 43.30 & 155.32 & 3.26 & 465.77 & 176.32 & 11.55 & 73.68 & 0.57 & 16.23 & 26.33 \\
\hline D18 & D-Group 2 & - & Cropland & 7.66 & 500 & 250 & 61.28 & 20.38 & 33.45 & 2.46 & 290.79 & 22.36 & 32.44 & 18.58 & 0.80 & 16.80 & 36.12 \\
\hline D20 & D-Group 2 & 40 & Cropland & 7.20 & 660 & 330 & 108.37 & 16.60 & 6.85 & 2.65 & 194.35 & 15.51 & 118.11 & 62.25 & 0.93 & 22.34 & 48.56 \\
\hline D22 & D-Group 2 & 61 & Cropland & 7.94 & 960 & 480 & 29.76 & 42.95 & 140.24 & 2.26 & 365.28 & 117.79 & 40.72 & 75.37 & 0.94 & 24.16 & 23.69 \\
\hline
\end{tabular}




\begin{tabular}{|c|c|c|c|c|c|c|c|c|c|c|c|c|c|c|c|c|c|}
\hline D23 & D-Group 2 & 19 & Grassland & 8.13 & 1930 & 965 & 7.06 & 9.44 & 109.17 & 0.88 & 38.34 & 131.14 & 6.12 & 86.96 & 1.27 & 32.38 & 29.59 \\
\hline D26 & D-Group 2 & 19 & Grassland & 7.55 & 940 & 470 & 45.65 & 39.66 & 177.37 & 3.60 & 655.11 & 83.60 & 5.49 & 29.17 & 1.82 & 36.65 & 23.99 \\
\hline D27 & D-Group 2 & - & Grassland & 7.42 & 520 & 260 & 82.19 & 24.60 & 19.68 & 2.49 & 389.60 & 18.42 & 6.11 & 7.46 & 3.22 & 49.78 & 51.27 \\
\hline D3 & D-Group 2 & 3 & Grassland & 7.76 & 720 & 360 & 58.15 & 28.29 & 67.78 & 3.84 & 410.31 & 23.32 & 11.02 & 32.68 & 3.54 & 57.62 & 29.35 \\
\hline D30 & D-Group 2 & 23 & Cropland & 8.13 & 1000 & 500 & 24.49 & 35.48 & 183.01 & 1.87 & 577.40 & 78.83 & 14.67 & 29.87 & 3.68 & 50.38 & 62.35 \\
\hline D4 & D-Group 2 & - & Grassland & 8.08 & 690 & 345 & 36.03 & 20.09 & 107.21 & 2.50 & 396.50 & 59.17 & 6.76 & 12.74 & 3.83 & 54.85 & 48.89 \\
\hline D5 & D-Group 2 & - & Cropland & 7.83 & 940 & 470 & 45.19 & 37.39 & 121.40 & 1.97 & 458.21 & 94.33 & 11.07 & 37.24 & 4.36 & 53.48 & 38.43 \\
\hline D6 & D-Group 2 & 6 & Cropland & 7.61 & 1270 & 635 & 68.89 & 46.54 & 191.94 & 2.80 & 690.16 & 139.07 & 3.56 & 52.21 & 4.61 & 58.28 & 38.39 \\
\hline D7 & D-Group 2 & 300 & Grassland & 7.60 & 640 & 320 & 46.12 & 17.40 & 39.92 & 2.44 & 214.16 & 53.81 & 7.54 & 28.42 & 5.50 & 65.69 & 22.79 \\
\hline D9 & D-Group 2 & 20 & Grassland & 7.42 & 820 & 410 & 56.04 & 32.99 & 35.57 & 1.96 & 312.51 & 40.63 & 18.45 & 31.25 & 6.29 & 80.71 & 37.22 \\
\hline D10 & D-Group 3 & 120 & Cropland & 7.34 & 440 & 220 & 24.26 & 9.91 & 9.73 & 1.27 & 133.81 & 3.48 & 5.42 & 5.00 & 0.42 & 18.25 & 14.92 \\
\hline D11 & D-Group 3 & 80 & Built-up land & 7.33 & 530 & 265 & 26.81 & 12.16 & 78.57 & 2.41 & 325.42 & 4.24 & 15.42 & 5.69 & 0.63 & 27.81 & 14.74 \\
\hline D14 & D-Group 3 & 180 & Built-up land & 7.85 & 540 & 270 & 11.72 & 10.32 & 16.41 & 1.05 & 104.21 & 6.94 & 9.23 & 6.56 & 0.70 & 22.77 & 10.96 \\
\hline D15 & D-Group 3 & 80 & Built-up land & 7.70 & 540 & 270 & 22.71 & 18.04 & 88.74 & 1.33 & 351.23 & 15.21 & 13.15 & 8.66 & 0.84 & 33.85 & 20.39 \\
\hline D16 & D-Group 3 & - & Grassland & 7.53 & 490 & 245 & 39.88 & 24.17 & 42.85 & 1.57 & 317.88 & 12.80 & 12.85 & 8.05 & 1.32 & 32.19 & 11.89 \\
\hline D2 & D-Group 3 & 200 & Built-up land & 7.61 & 460 & 230 & 38.78 & 13.46 & 19.99 & 1.29 & 213.85 & 8.34 & 8.05 & 5.47 & 1.44 & 45.36 & 20.30 \\
\hline D21 & D-Group 3 & 35 & Unused & 8.05 & 510 & 255 & 10.80 & 10.88 & 36.43 & 1.41 & 140.90 & 10.15 & 20.45 & 7.64 & 1.86 & 52.84 & 19.73 \\
\hline D28 & D-Group 3 & - & Built-up land & 7.31 & 790 & 395 & 14.78 & 10.18 & 29.58 & 1.23 & 114.61 & 25.99 & 3.62 & 15.11 & 2.07 & 48.45 & 16.75 \\
\hline D29 & D-Group 3 & 75 & Built-up land & 7.54 & 590 & 295 & 13.85 & 10.09 & 12.77 & 1.39 & 101.42 & 5.72 & 8.29 & 7.40 & 3.15 & 59.63 & 15.04 \\
\hline D8 & D-Group 3 & - & Cropland & 7.74 & 490 & 245 & 21.60 & 17.12 & 53.38 & 1.35 & 263.90 & 8.30 & 4.67 & 10.21 & 3.36 & 59.60 & 12.28 \\
\hline
\end{tabular}

156 EC = electrical conductivity; TDS = total dissolved solids; SAR = sodium adsorption ratio; \%Na = the Sodium percentage; WQI 157 = water quality index.

158 To investigate the accuracy of chemical analysis, the ionic charge balance error (ICBE)

159 of anions and cations was calculated by the following formula (Eq.1):

160

$$
I C B E=\frac{\sum \text { Cations }-\sum \text { Anions }}{\sum \text { Cations }+\sum \text { Anions }} \times 100
$$

161 where the concentrations unit of cations and anions are meq/L. The calculation results 162 of ICBE in the study area were within $\pm 5 \%$, which indicated that the quality of 163 groundwater chemical data is reliable (Ismail et al. 2019). 


\subsection{Multivariate data analysis}

165 The Q-mode hierarchical cluster analysis (HCA) was employed to divide samples into

166 various groups using the Ward's method (J.C. 1974). For those water quality indices

167 not normally distributed, a log transformation was conducted (Ismail et al. 2019). HCA

168 can present information about the evolution of groundwater bodies, and determine the

169 hydrochemical facies.

170 We investigated whether there were seasonal differences in groundwater by comparing

171 solute concentrations of groundwater between flood season and dry season with a

172 Wilcoxon paired rank sum test. A non-parametric test was used because the

173 concentrations of ions were not normally distributed (Bernal et al. 2015). It was

174 observed that only $\mathrm{HCO}_{3}{ }^{-}$of flood season and $\mathrm{pH}$ and $\mathrm{K}^{+}$of dry season were normally

175 distributed. Therefore, it is necessary to substitute the original data of other non-normal

176 distribution parameters into the formula of $x^{\prime}=\log 10(x)$ for $\log$-transformation. The

177 calculation results showed that the remaining parameters were corrected to be

178 normalized except $\mathrm{Cl}^{-}$of flood season and thus it was excluded.

$179 \quad$ 2.4 Water Quality Analysis

180 The groundwater quality for drinking purposes was assessed based on an improved

181 form of water quality index (WQI, Eq.2-3) (Aghababazadeh et al. 2016):

$$
\begin{gathered}
W_{i}=\frac{w_{i}}{\sum w_{i}} \\
W Q I=\sum\left[W_{i} \times\left(\frac{C_{i}}{S_{i}}\right) \times 100\right]
\end{gathered}
$$

184 where $W_{i}$ and $w_{i}$ are the weight and relative weight of the $i_{\text {th }}$ parameter, respectively

185 (Table 3); $C_{i}$ is the concentrations of the $i_{\text {th }}$ parameter; $S_{i}$ is the permissible limit for the 
186

187

188

189

190

191

192

193

194

195

196

197

198

199

200

201

202

203

204

205

206

$i_{\text {th }}$ parameter. Based on WQI values, groundwater quality can be divided into five groups: excellent $(<50)$, good $(50-100)$, poor $(100-200)$, very poor $(200-300)$, and unsuitable $(\geq 300)$.

For irrigation purpose, $\mathrm{Na}^{+}$in groundwater can change the salinity of the soil and offset the osmotic pressure of the crops, which further affects the plant root water uptake and photosynthesis (FK et al., 2015). The sodium hazard can be estimated by the sodium adsorption ratio (SAR, Eq.4) (Banoeng-Yakubo et al.) and soluble sodium percentage (\%Na, Eq.5) (Santacruz et al. 2017):

$$
\begin{gathered}
S A R=\frac{\left[\mathrm{Na}^{+}\right]}{\sqrt{\frac{\left[C a^{2+}\right]+\left[M g^{2+}\right]}{2}}} \\
\% N a=\frac{N a^{+}}{N a^{+}+K^{+}+C a^{2+}+M^{2+}} \times 100 \%
\end{gathered}
$$

where all ions are expressed in meq/L. According to SIAR values, sodium hazard can be classified into four categories, i.e., low $(<10)$, medium $(10-18)$, high $(18-26)$, and very high $(\geq 26)$. Also, the classification of irrigation water quality based on $\% \mathrm{Na}$ is as follows: suitable $(<30)$, marginally suitable (30-60), and unsuitable $(\geq 60)$. The salinity hazard is divided into four ranks by EC ( $\mu \mathrm{S} / \mathrm{cm})$ : low $(<250)$, medium (250 -750), high (750-2250), and very high ( $\geq 2250)$.

To show the spatial variation of hydrochemical parameters (i.e., TDS, $\mathrm{Ca}^{2+}, \mathrm{Na}^{+}, \mathrm{NO}_{3}{ }^{-}$) and WQI values, the ordinary kriging was used in this study since it overall outperformed other methods.

\subsection{Quantifying contribution of different solute sources}

The forward model was applied to quantify the relative contributions of atmospheric 
208 inputs and rock weathering to dissolved solutes (Wu et al., 2005). In this study, 209 anthropogenic input was also considered as one of the solutes sources by using nitrate 210 as an indicator (Li et al. 2019c; Xiao et al. 2015). The overall flow chart and specific 211 equations used for quantification of source contribution to dissolved solutes were 212 presented in Fig. 2.

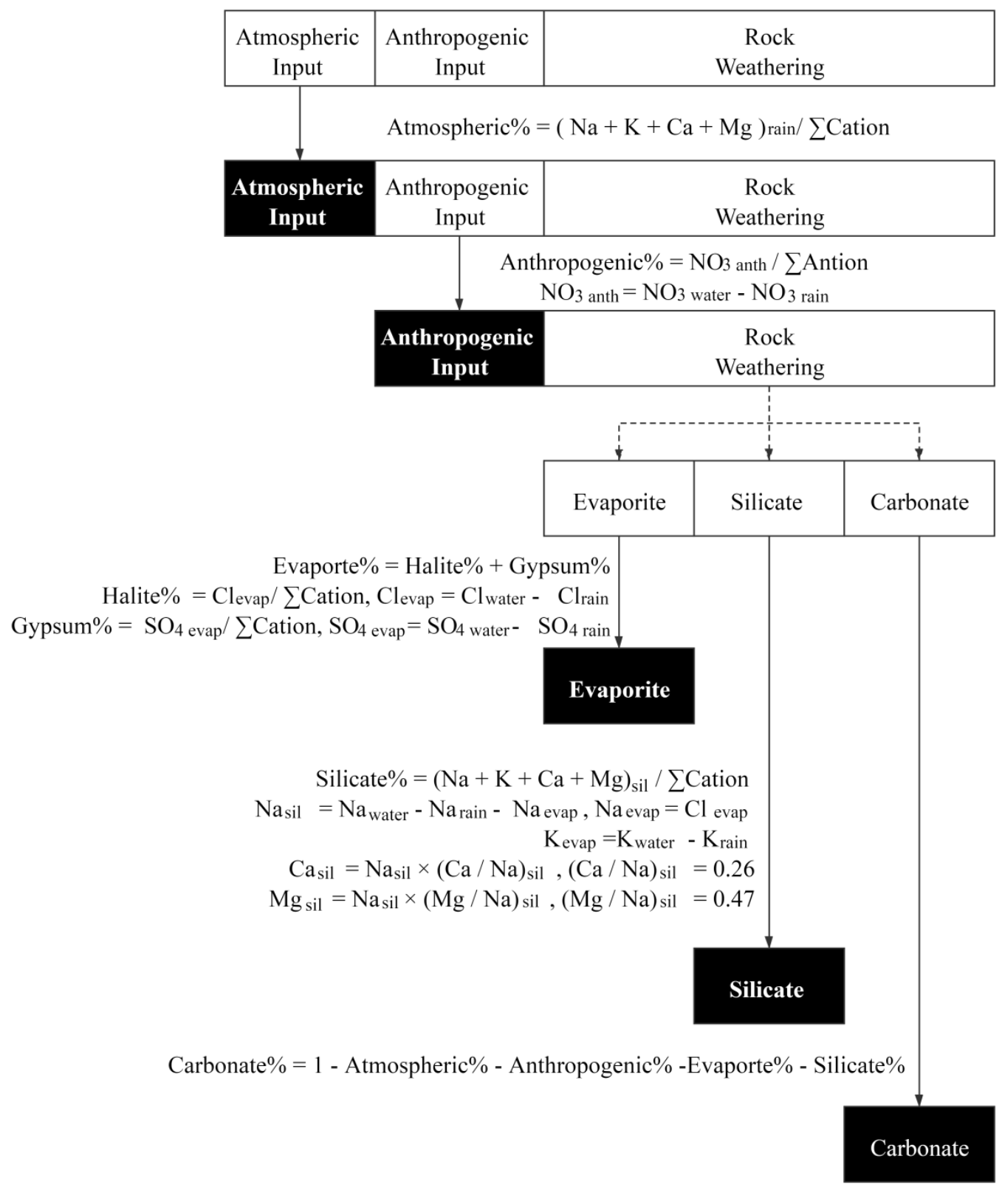

214 Fig. 2 Overall framework of forward model for quantification of source contribution to dissolved 215 solutes in groundwater. 
216 According to Xiao et al. (2016), the mean value of $\mathrm{Ca}^{2+} / \mathrm{Na}^{+}$in bedrock from the upper

217 to lower reaches of the Yellow River is $0.24-0.31$, and the average value of $\mathrm{Mg}^{2+} / \mathrm{Na}^{+}$

218 is $0.35-0.51$ (Xiao 2016). In this study, we took the mean values of $\mathrm{Ca}^{2+} / \mathrm{Na}^{+}(0.26)$ and

$219 \mathrm{Mg}^{2+} / \mathrm{Na}^{+}(0.47)$ in bedrock to calculate the contribution of silicate weathering.

\section{Results}

\subsection{Hydrochemical characteristics}

222 Table 2 listed the hydrochemical statistics of groundwater samples in different seasons

223 on the Loess Plateau. In the flood season, $\mathrm{pH}$ ranged between 6.66 and 8.63 with an

224 average of 7.65 , and the TDS concentration ranged from 247 to $1410 \mathrm{mg} / \mathrm{L}$ with an 225 average of $445 \mathrm{mg} / \mathrm{L} . \mathrm{Ca}^{2+}$ (average $76.80 \mathrm{mg} / \mathrm{L}$ ) and $\mathrm{Na}^{+}$(average $50.90 \mathrm{mg} / \mathrm{L}$ ) were 226 the dominant cations, while $\mathrm{HCO}_{3}{ }^{-}$(average $\left.355.82 \mathrm{mg} / \mathrm{L}\right)$ was the dominant anion. The 227 contents of ions were in the order of $\mathrm{Ca}^{2+}>\mathrm{Na}^{+}>\mathrm{Mg}^{2+}>\mathrm{K}^{+}$and $\mathrm{HCO}_{3}{ }^{-}>\mathrm{SO}_{4}{ }^{2-}>\mathrm{Cl}^{-}>$ $228 \mathrm{NO}_{3}^{-}$.

229 Table 1 Descriptive statistics of hydrochemical parameters of groundwater in different seasons on 230 the Loess Plateau

\begin{tabular}{|c|c|c|c|c|c|c|c|c|c|c|c|c|}
\hline Statistics & & $\mathrm{pH}$ & $\mathrm{EC}$ & TDS & $\mathrm{Ca}^{2+}$ & $\mathrm{Mg}^{2+}$ & $\mathrm{Na}^{+}$ & $\mathrm{K}^{+}$ & $\mathrm{HCO}_{3}^{-}$ & $\mathrm{SO}_{4}{ }^{2-}$ & $\mathrm{NO}_{3}^{-}$ & $\mathrm{Cl}^{-}$ \\
\hline \multicolumn{13}{|c|}{ Flood Season (37 samples) } \\
\hline \multirow{2}{*}{ F-grounp 1} & Mean & 6.75 & 2322 & 1194 & 203.64 & 74.41 & 182.19 & 3.99 & 664.05 & 173.10 & 114.76 & 310.15 \\
\hline & SD & 0.13 & 745 & 305 & 49.60 & 6.58 & 62.56 & 0.23 & 265.37 & 6.91 & 72.38 & 213.46 \\
\hline \multirow{2}{*}{ F-grounp 2} & Mean & 7.81 & 842 & 422 & 87.64 & 24.08 & 47.52 & 3.47 & 418.95 & 41.22 & 16.78 & 20.63 \\
\hline & SD & 0.55 & 367 & 182 & 39.00 & 9.73 & 42.42 & 2.78 & 115.74 & 47.80 & 15.89 & 28.80 \\
\hline \multirow{2}{*}{ F-grounp 3} & Mean & 7.49 & 713 & 379 & 34.88 & 12.87 & 35.51 & 2.33 & 183.46 & 22.70 & 27.78 & 17.81 \\
\hline & SD & 0.25 & 196 & 92 & 17.72 & 4.20 & 34.53 & 1.23 & 60.89 & 18.32 & 42.55 & 28.39 \\
\hline \multirow{4}{*}{ Total } & Min & 6.66 & 417 & 247 & 18.46 & 5.08 & 4.17 & 1.04 & 88.62 & 2.73 & 1.53 & 0.98 \\
\hline & Max & 8.63 & 2848 & 1410 & 238.71 & 79.06 & 226.42 & 12.62 & 851.69 & 177.99 & 165.93 & 461.09 \\
\hline & Mean & 7.65 & 880 & 445 & 76.80 & 23.16 & 50.90 & 3.12 & 355.82 & 42.34 & 25.64 & 35.36 \\
\hline & SD & 0.52 & 485 & 241 & 51.46 & 15.69 & 51.15 & 2.35 & 170.3 & 50.79 & 36.69 & 80.34 \\
\hline \multicolumn{13}{|c|}{ Dry Season (27 samples) } \\
\hline D-grounp 1 & Mean & 7.51 & 2030 & 1015 & 33.13 & 61.67 & 1213.50 & 2.03 & 2960.39 & 316.35 & 78.50 & 114.35 \\
\hline
\end{tabular}




\begin{tabular}{rcrrrrrrrrrrrr} 
& SD & - & - & - & - & - & - & - & - & - & - \\
\multirow{2}{*}{ D-grounp 2 } & Mean & 7.66 & 888 & 444 & 55.29 & 30.13 & 90.43 & 2.45 & 380.32 & 77.78 & 20.69 & 38.39 \\
& SD & 0.31 & 360 & 180 & 28.78 & 11.01 & 65.18 & 0.72 & 168.85 & 56.42 & 28.00 & 24.45 \\
\multirow{2}{*}{ D-grounp 3 } & Mean & 7.60 & 538 & 269 & 22.52 & 13.63 & 38.84 & 1.43 & 206.72 & 10.12 & 10.11 & 7.98 \\
& SD & 0.24 & 99 & 49 & 10.42 & 4.73 & 27.43 & 0.37 & 100.21 & 6.66 & 5.31 & 2.97 \\
& Min & 7.20 & 440 & 220 & 7.06 & 9.44 & 6.85 & 0.88 & 38.34 & 3.48 & 3.56 & 5.00 \\
\multirow{2}{*}{ Total } & Max & 8.13 & 2030 & 1015 & 116.01 & 61.67 & 1213.50 & 3.84 & 2960.39 & 316.35 & 118.11 & 114.35 \\
& Mean & 7.63 & 801 & 400 & 42.33 & 25.19 & 112.92 & 2.06 & 411.59 & 61.56 & 18.91 & 29.94 \\
& SD & 0.27 & 409 & 205 & 27.80 & 13.97 & 227.42 & 0.77 & 535.28 & 74.35 & 25.11 & 29.18 \\
\hline
\end{tabular}

231 The unit of $\mathrm{EC}$ is $\mu \mathrm{S} / \mathrm{cm}$; $\mathrm{pH}$ is dimensionless. Other parameters have unit of $\mathrm{mg} / \mathrm{L}$.

232 In the dry season, the $\mathrm{pH}$ value varied from 7.20 to 8.13 with a mean of 7.63 , which 233 indicates an alkaline environment. TDS concentration ranged from 220 to $1015 \mathrm{mg} / \mathrm{L}$ 234 with an average of $400 \mathrm{mg} / \mathrm{L}$. The dominant cation was $\mathrm{Na}^{+}$(average $112.92 \mathrm{mg} / \mathrm{L}$ ), 235 followed by $\mathrm{Ca}^{2+}$ (average $42.33 \mathrm{mg} / \mathrm{L}$ ), $\mathrm{Mg}^{2+}$ (average $25.19 \mathrm{mg} / \mathrm{L}$ ), and $\mathrm{K}^{+}$(average $2362.06 \mathrm{mg} / \mathrm{L})$. The abundance of anions was that $\mathrm{HCO}_{3}{ }^{-}$(average $\left.411.59 \mathrm{mg} / \mathrm{L}\right)>\mathrm{SO}_{4}{ }^{2-}$ 237 (average $61.56 \mathrm{mg} / \mathrm{L})>\mathrm{Cl}^{-}($average $29.94 \mathrm{mg} / \mathrm{L})>\mathrm{NO}_{3}{ }^{-}($average $18.91 \mathrm{mg} / \mathrm{L})$, which 238 is the same as the order of anion concentration in the flood season. As shown in Table 2392 , the standard deviation of major cations and anions was highly dispersive, indicating 240 that the chemical composition of groundwater exhibited a large spatial difference. Fig. 2413 showed the Wilcoxon test results of major ions content in different seasons. As shown 242 in Fig. 3, the difference of most ions was not significant $(\mathrm{p}>0.05)$ except for $\mathrm{Ca}^{2+}$ $243(\mathrm{p}=0.0078)$ and $\mathrm{Na}^{+}(\mathrm{p}=0.033)$, which implied the contents of $\mathrm{Ca}^{2+}$ and $\mathrm{Na}^{+}$in 244 groundwater changed significantly in the two seasons. This is the reason why the order 245 of abundance of major cations is different in the flood season and the dry season. 
(a)

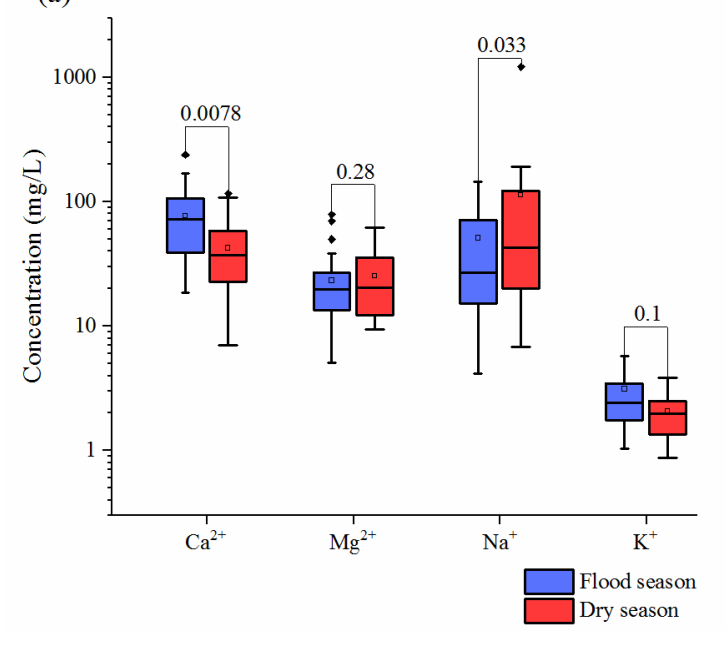

(b) $\quad 0.62$

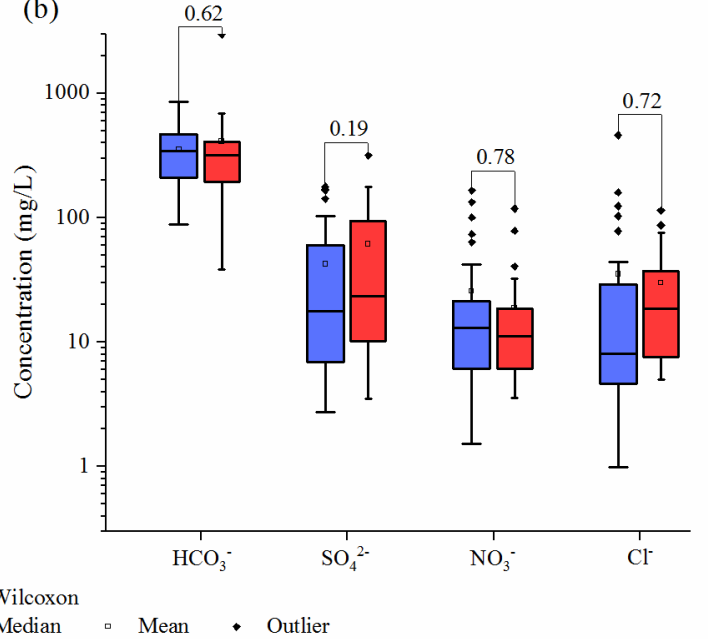

247 Fig. 3 Box plots showing variations of major cations (a) and anions (b) concentrations in 248 groundwater in two different seasons ( $\mathrm{p}<0.05$ means significant difference).

\subsection{Hydrochemical facies}

250 By using HCA, three clusters were identified for both the flood season (F-Group 1, 2 251 and 3) and the dry season (D-Group 1, 2 and 3) based on hydrochemical parameters 252 (Table 1 and Fig. 4a). F-Group1, consisting of samples F28 and F30 (6\% of total 253 samples), was characterized by the highest average concentrations of $\mathrm{Ca}^{2+}, \mathrm{Mg}^{2+}, \mathrm{Na}^{+}$, $254 \mathrm{~K}^{+}, \mathrm{HCO}_{3}^{-}, \mathrm{SO}_{4}^{2-}, \mathrm{Cl}^{-}, \mathrm{NO}_{3}^{-}$, and $\mathrm{TDS}$ and the lowest $\mathrm{pH}$ value. The dominant 255 hydrochemical type was $\mathrm{Ca} \cdot \mathrm{Na}-\mathrm{HCO}_{3} \cdot \mathrm{Cl}$. As shown in Fig. 4b, the samples of F256 Group1 were mainly distributed in Yan'an City in northern Shaanxi, where there were 257 a lot of petroleum industry, and the increase in salinization observed in this system may 258 be potentially related to petroleum production. Approximately $62 \%$ of the samples $(\mathrm{n}=$ 259 23) were clustered into F-Group2, which was characterized by the higher mean contents 260 of $\mathrm{Ca}^{2+}, \mathrm{Mg}^{2+}, \mathrm{Na}^{+}, \mathrm{K}^{+}, \mathrm{HCO}_{3}{ }^{-}, \mathrm{SO}_{4}{ }^{2-}, \mathrm{Cl}^{-}, \mathrm{TDS}$, and $\mathrm{pH}$ and the lowest mean

261 concentrations of $\mathrm{NO}_{3}{ }^{-}$, and the hydrochemical type of which was dominated by $\mathrm{Ca}$ $262 \mathrm{HCO}_{3}$. These samples were mainly distributed in loess tablelands with thick loess and 263 large groundwater storage in the southeast of Gansu Province and the southwest of 264 Shaanxi Province. About $32 \%$ of the samples $(n=12)$ were classified as F-Group3, 
which was characterized by the lowest contents of $\mathrm{Ca}^{2+}, \mathrm{Mg}^{2+}, \mathrm{Na}^{+}, \mathrm{K}^{+}, \mathrm{HCO}_{3}^{-}, \mathrm{SO}_{4}{ }^{2-}$,

$266 \mathrm{Cl}^{-}$, and TDS and the higher contents of $\mathrm{NO}_{3}{ }^{-}$and $\mathrm{pH}$ values, and distributed in the 267 southern junction of Gansu and Ningxia. $\mathrm{Ca} \cdot \mathrm{Mg}-\mathrm{HCO}_{3}$ was the dominant 268 hydrochemical type for F-Group3.

269 D-Group 1 consisted of only one groundwater sample (sample D13) with the highest 270 concentrations of $\mathrm{Mg}^{2+}, \mathrm{Na}^{+}, \mathrm{HCO}_{3}{ }^{-}, \mathrm{SO}_{4}{ }^{2-}, \mathrm{Cl}^{-}, \mathrm{NO}_{3}{ }^{-}$, and TDS, which was located in 271 Pucheng County in Southern Shaanxi, and the hydrochemical type of which was Na$272 \mathrm{HCO}_{3}$. This may be related to the massive use of mirabilite in the local pyrotechnic 273 manufacturing industry. Thus, D-Group 1 was regarded as an indicator of human 274 activities. Nearly $70 \%$ of the samples $(n=16)$ were classified as D-Group 2, which 275 was characterized by the higher mean concentrations of $\mathrm{Mg}^{2+}, \mathrm{Na}^{+}, \mathrm{HCO}_{3}{ }^{-}, \mathrm{SO}_{4}^{2-}, \mathrm{Cl}^{-}$, $276 \mathrm{NO}_{3}{ }^{-}$, and TDS and the highest mean concentrations of $\mathrm{Ca}^{2+}, \mathrm{K}^{+}$, and $\mathrm{pH}$, The dominant 277 hydrochemical type was $\mathrm{Na} \cdot \mathrm{Ca}-\mathrm{HCO}_{3} \cdot \mathrm{SO}_{4}$. About $37 \%$ of groundwater samples $(\mathrm{n}=$ 278 10) were clustered into D-Group 3, which was characterized by the lowest mean 279 contents of $\mathrm{Ca}^{2+}, \mathrm{Mg}^{2+}, \mathrm{Na}^{+}, \mathrm{K}^{+}, \mathrm{HCO}_{3}{ }^{-}, \mathrm{SO}_{4}{ }^{2-}, \mathrm{Cl}^{-}$, and $\mathrm{NO}_{3}{ }^{-}$, and the hydrochemical 280 type of which was dominanted by $\mathrm{Na}-\mathrm{HCO}_{3}$.

281

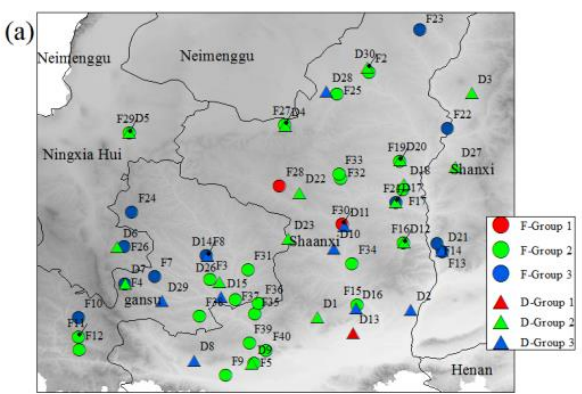

(b)

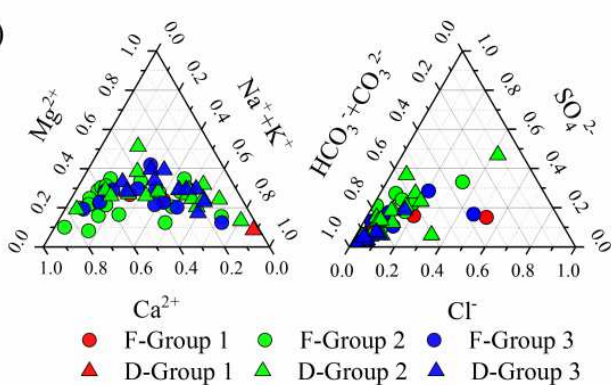

282 Fig. 4 Spatial distribution (a) and ternary diagrams (b) of the six clusters (F-Group 1-3, D-Group1283 3) in the study area.

\subsection{Groundwater quality for domestic purpose}

Table 3 listed the statistics and weight assignment of the chemical composition of 
groundwater exceeding acceptable limits in the flood and dry season. Obviously, $\mathrm{Mg}^{2+}$ and $\mathrm{SO}_{4}{ }^{2-}$ concentrations in the flood season and $\mathrm{Mg}^{2+}, \mathrm{Cl}^{-}$and $\mathrm{K}^{+}$concentrations in the 288 dry season were within the allowable limits of drinking water set by the WHO. However, 289 the concentration of other water quality parameters exceeded their respective acceptable limits. In the flood season, approximately $43 \%, 3 \%, 6 \%, 14 \%, 3 \%$, and $3 \%$

291 of groundwater samples had $\mathrm{Ca}^{2+}, \mathrm{Na}^{+}, \mathrm{K}^{+}, \mathrm{NO}_{3}^{-}, \mathrm{Cl}^{-}$, and TDS exceeding the 292 acceptable limits, respectively. In the dry season, $11 \%, 4 \%, 7 \%, 4 \%$, and $4 \%$ of the 293 samples exhibited $\mathrm{Ca}^{2+}, \mathrm{Na}^{+}, \mathrm{NO}_{3}{ }^{-}, \mathrm{SO}_{4}{ }^{2-}$, and TDS exceeding the acceptable limits, 294 respectively.

295 Table 3 Statistics and weight assignment of the chemical composition of groundwater exceeding 296 acceptable limits in the flood season and the dry season.

\begin{tabular}{|c|c|c|c|c|c|c|c|c|}
\hline \multirow{2}{*}{ Parameter } & \multirow{2}{*}{ Unit } & \multirow{2}{*}{$\begin{array}{l}\text { WHO } \\
\text { (2011) }\end{array}$} & \multicolumn{2}{|c|}{2018 Flood season $(\mathrm{N}=37)$} & \multicolumn{2}{|c|}{2019 Dry season $(\mathrm{N}=27)$} & \multicolumn{2}{|c|}{ Parameters for WQI calculation } \\
\hline & & & NSEL & $\%$ of SEL & NSEL & $\%$ of SEL & $w_{i}$ & $W_{i}$ \\
\hline TDS & $\mathrm{mg} \cdot \mathrm{L}^{-1}$ & 1000 & F28 & 3 & D13 & 4 & 5 & 0.15 \\
\hline $\mathrm{SO}_{4}^{2-}$ & $\mathrm{mg} \cdot \mathrm{L}^{-1}$ & 250 & & 0 & D13 & 4 & 5 & 0.15 \\
\hline $\mathrm{NO}_{3}^{-}$ & $\mathrm{mg} \cdot \mathrm{L}^{-1}$ & 50 & $\mathrm{~F} 14,17,21,28,30$ & 14 & D13,20 & 7 & 5 & 0.15 \\
\hline $\mathrm{Cl}^{-}$ & $\mathrm{mg} \cdot \mathrm{L}^{-1}$ & 250 & F28 & 3 & & 0 & 5 & 0.15 \\
\hline $\mathrm{Ca}^{2+}$ & $\mathrm{mg} \cdot \mathrm{L}^{-1}$ & 75 & $\begin{array}{c}\mathrm{F} 2,9,14-17,19,27-30 \\
33-34,36-37,40\end{array}$ & 43 & $\mathrm{D} 1,20,27$ & 11 & 3 & 0.09 \\
\hline $\mathrm{Mg}^{2+}$ & $\mathrm{mg} \cdot \mathrm{L}^{-1}$ & 100 & & 0 & & 0 & 3 & 0.09 \\
\hline $\mathrm{Na}^{+}$ & $\mathrm{mg} \cdot \mathrm{L}^{-1}$ & 200 & F28 & 3 & D13 & 4 & 4 & 0.12 \\
\hline $\mathrm{K}^{+}$ & $\mathrm{mg} \cdot \mathrm{L}^{-1}$ & 10 & F29,36 & 5 & & 0 & 3 & 0.09 \\
\hline
\end{tabular}

Note: NSEL $=$ number of samples exceeding acceptable limit; $\%$ of SEL $=\%$ of samples exceeding acceptable limit.

297 The WQI values ranged from 12 to 132 (average 36) and from 11 to 149 (average 33) 298 in the flood season and the dry season, respectively (Table 1). Slight differences in 299 groundwater quality for domestic purpose were found in the two seasons. In the flood 300 season, about $81 \%, 14 \%$ and $5 \%$ of the samples were classified as excellent, good and 301 poor quality, respectively. Compared with the flood season, the percentage of excellent quality water (89\%) increased, while the percentage of good (7\%) and poor quality (4\%) 
decreased in the dry season.

\subsection{Groundwater quality for irrigation purpose}

As shown in Table 1, the SAR values ranged between 0.14 and 5.44 (average 1.40) and between 0.16 and 28.62 (average 3.20) in the flood season and the dry season, respectively. Obviously, groundwater in the flood season was suitable for irrigation, while only one sample (sample D13) was unsuitable for irrigation in the dry season. \%Na values varied from 4.19 to 72.70 with an average 27.37 in the flood season, which was lower those in the dry season (from 5.10 to 88.60, average 41.73). Approximately $5.4 \%$ of the flood season samples and $11.1 \%$ of the dry season samples had $\mathrm{Na} \%$ values greater than 60 , indicating that these groundwater were unsuitable for irrigation. EC values ranged between 417 and $2848 \mu \mathrm{S} / \mathrm{cm}$ (average $880 \mu \mathrm{S} / \mathrm{cm}$ ) and between 440 and $2030 \mu \mathrm{S} / \mathrm{cm}$ (average $801 \mu \mathrm{S} / \mathrm{cm}$ ) in the flood season and the dry season, respectively. Most of the groundwater samples (except sample F28) in both seasons were classified as good quality $(250<\mathrm{EC}<750 \mu \mathrm{S} / \mathrm{cm})$ or permissible quality $(250-750 \mu \mathrm{S} / \mathrm{cm})$ for irrigation.

The diagrams developed by the USSL (1954) and Wilcox (1948) have been widely applied to evaluate the groundwater quality for irrigation (Loh et al. 2019). As shown in Fig. 5a, 35 samples (19 collected from the flood season and 16 collected from the dry season) were plotted in the C2-S1 zone, showing good quality for irrigation; 17 flood samples and 10 dry samples were plotted in the C3-S1 zone, indicating moderate quality for irrigation. Moreover, samples D13 and F28 were plotted in C3-S4 and S1C3 zones, respectively, signifying unsuitable for irrigation owing to high salinity or high sodium hazard. The Wilcox diagram (Fig. 5b) showed that $89 \%$ of the samples were suitable for irrigation; 5 samples ( 2 collected from the flood season and 3 collected from the dry season) were plotted in the "doubtful to permissible" zone because of 
(a)

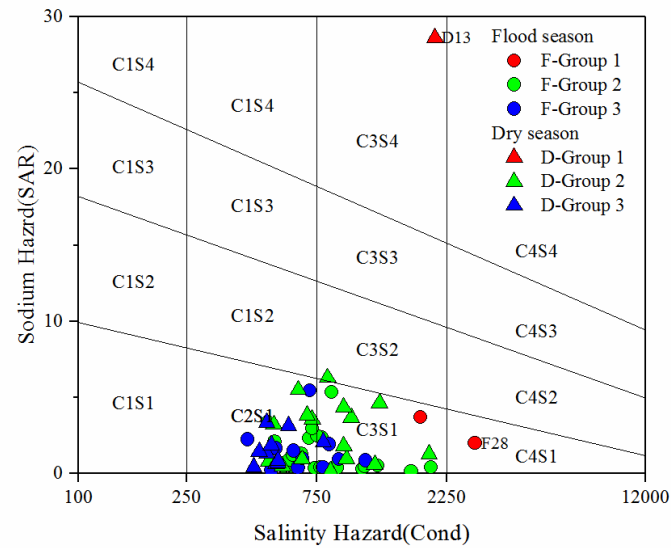

(b)

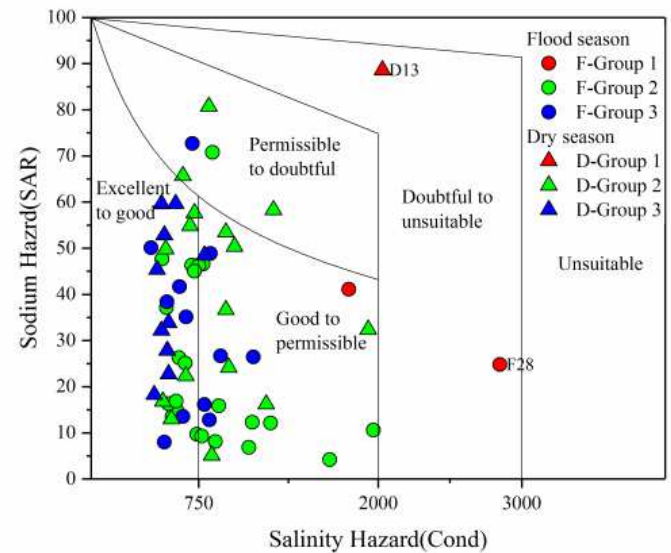

Fig. 5 USSL diagram (a) and Wilcox diagram (b) to investigate the quality of irrigation water.

\section{Discussion}

\subsection{Spatiotemporal variations in the hydrochemical characteristics}

To investigate the spatiotemporal variations in the hydrochemcial characteristics, we calculated the concentration differences of different indices ( $\triangle \mathrm{TDS}, \Delta \mathrm{Ca}^{2+}, \Delta \mathrm{Na}^{+}$and $\Delta \mathrm{NO}_{3}{ }^{-}$) between the dry season and the flood season (Fig. 6). For example, $\Delta \mathrm{TDS}=$

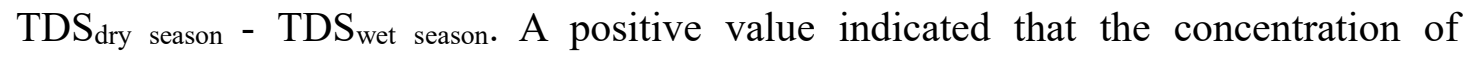
hydrochemcial indices increase from the flood season to the dry season, while a negative value suggests that the concentration decreases. In previous studies, the groundwater level near the river was relatively shallow, and it was susceptible to the dilution effect of precipitation and flash flood event during the flood season, making the concentration of groundwater ions in the flood season lower than that in the dry season (Guo et al. 2019; Masoud et al. 2018). However, in this study, the average contents of TDS, $\mathrm{Ca}^{2+}$ and $\mathrm{NO}_{3}{ }^{-}$were lower in the dry season (Table 2), which was related to the generally deeper groundwater level in the vadose zone. As shown in Fig. 
346 6a-d, most of the groundwater, especially in the central and southeast, showed negative $347 \Delta \mathrm{TDS}, \Delta \mathrm{Ca}^{2+}$ and $\Delta \mathrm{NO}_{3}{ }^{-}$values. The areas with negative values of $\Delta \mathrm{TDS}, \Delta \mathrm{Ca}^{2+}$ and $348 \Delta \mathrm{NO}_{3}{ }^{-}$accounted for $79 \%, 83 \%$, and $88 \%$ of the study area, respectively, indicating that 349 the contents of TDS, $\mathrm{Ca}^{2+}$ and $\mathrm{NO}_{3}{ }^{-}$were generally higher in the flood season.

$350 \mathrm{The}^{+}{ }^{+}$concentrations increased in most areas from the flood season to the dry season. 351 Especially, the largest increase of $\mathrm{Na}^{+}$concentrations $\left(\Delta \mathrm{Na}^{+}=1185.0 \mathrm{mg} / \mathrm{L}\right)$ occurred 352 in Pucheng County, Shaanxi Province (sample D13) (Fig. 6c). $\Delta \mathrm{NO}_{3}^{-}$was used to 353 determine the effect of anthropogenic activities on the spatiotemporal evolution (Fig. 354 6d). As shown in Fig. 6d, groundwater with increased $\mathrm{NO}_{3}{ }^{-}$concentration was mainly 355 distributed in areas where farmland was the main land use type (samples D13 and D20), 356 indicating that anthropogenic activities played a significant role in groundwater 357 chemistry in these areas. Figs. 6e and $6 \mathrm{f}$ showed the spatial distribution of WQI values 358 in the flood season and the dry season, respectively. The WQI values of groundwater 359 were higher in the northern Loess Plateau, which may be related to higher salt contents 360 of groundwater caused by strong evaporation and sparse rainfall in the north. In addition, 361 local groundwater quality may also be affected by anthropogenic activities. For 362 example, in the dry season, the WQI value in a limited region in the south around 363 sample D13 was higher than other regions, which was possibly caused by 364 anthropogenic inputs from firework factories. 


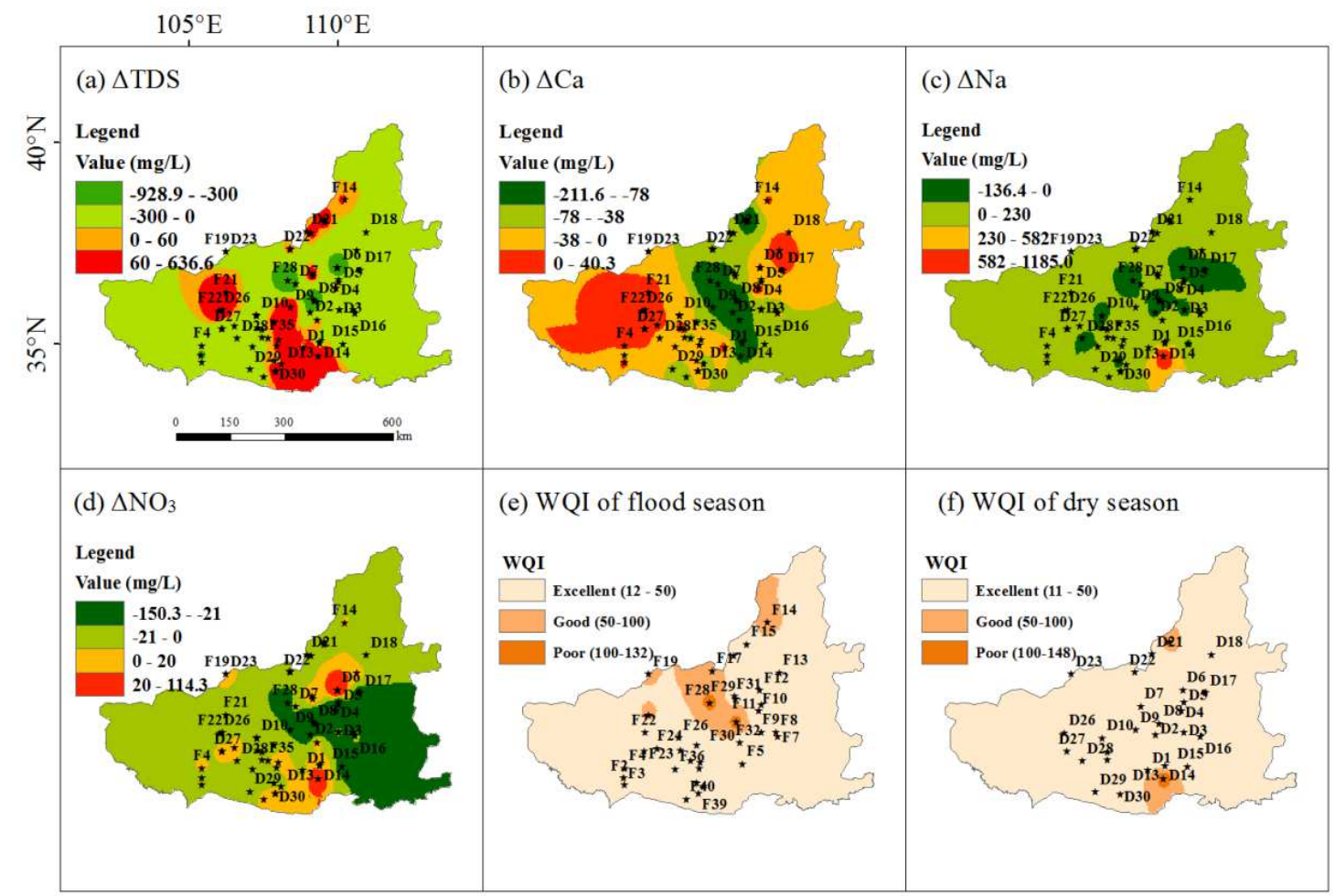

366 Fig. 6 Spatial patterns in the seasonal difference of TDS (a), $\mathrm{Ca}^{2+}(\mathrm{b}), \mathrm{Na}^{+}(\mathrm{c}), \mathrm{NO}_{3}^{-}(\mathrm{d})$, and WQI

367 in the flood season (e) and the dry season (f).

\subsection{Qualitative analysis of ion sources}

369 Gibbs plots (Gibbs, 1970) was used to illustrate three significant natural factors 370 controlling groundwater chemistry by plotting $\mathrm{Na}^{+} /\left(\mathrm{Na}^{+}+\mathrm{Ca}^{2+}\right)$ or $\mathrm{Cl}^{-} /\left(\mathrm{Cl}^{-}+\mathrm{HCO}_{3}^{-}\right)$

371 versus TDS (Fig. 7). Fig. 7 showed that $97.3 \%$ of samples in the flood season and $96.3 \%$

372 in the dry season fell into the rock weathering dominance zone, suggesting that water373 rock interactions and rock weathering were the predominantly factors controlling the 374 chemical composition. Moreover, two samples (F28 and D13) were plotted in the 375 evaporation dominance zone, which indicated that evaporation also had a certain effect 376 on groundwater chemistry. 

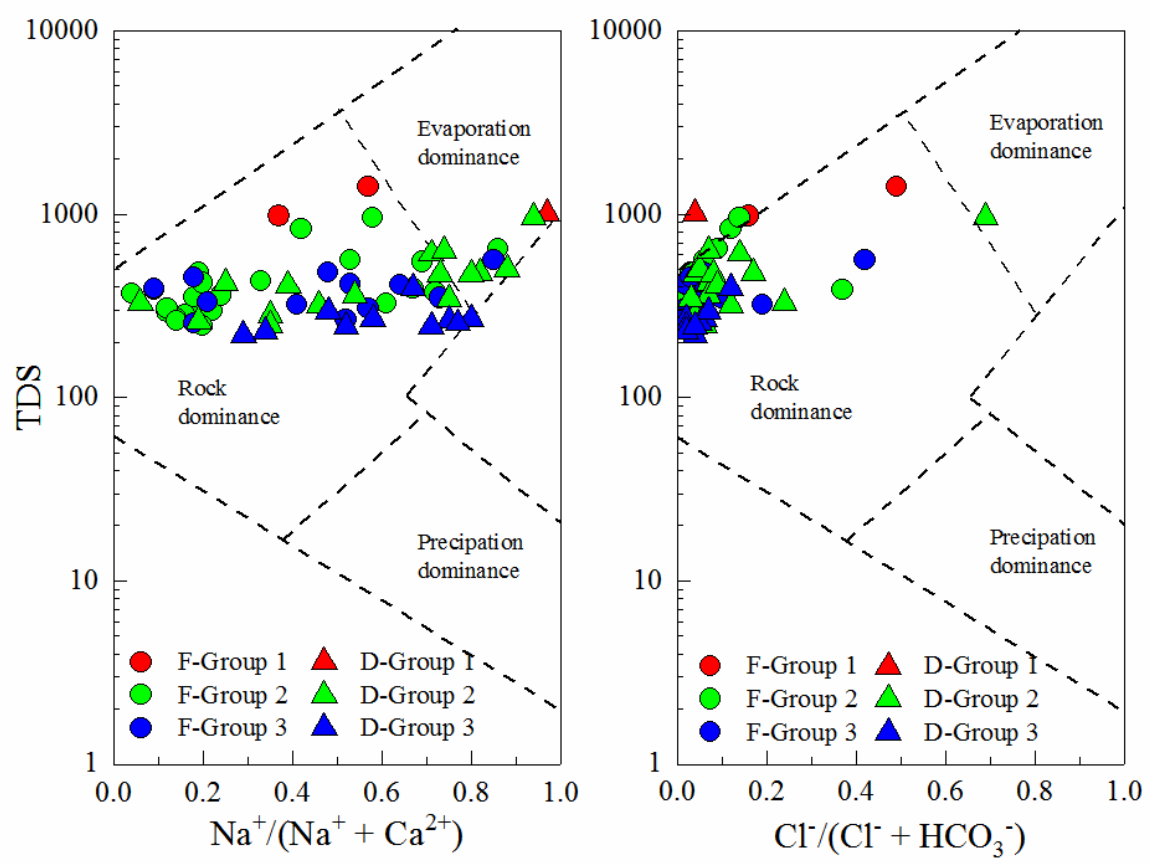

378 Fig. 7 Scatterplots of (a) TDS versus $\mathrm{Na} /\left(\mathrm{Na}+\mathrm{Ca}\right.$ ) and (b) TDS versus $\mathrm{Cl} /\left(\mathrm{Cl}+\mathrm{HCO}_{3}\right)$ to illustrate 379 the dominant processes that control dissolved solutes.

380 The Na-normalized molar ratios (Gaillardet et al., 1995) was used to explore the effect

381 of rock weathering on groundwater chemistry by dividing solute sources into evaporite 382 dissolution, silicate and carbonate rock weathering (Fig. 8). As shown in Fig. 8, most 383 of the samples in the flood season were distributed in the middle and upper right areas, 384 which indicated that the dissolved solutes in the flood season were mainly controlled 385 by silicate and carbonate weathering. The samples in the dry season were mainly 386 located in the middle and left lower areas, indicating the dominance of silicate 387 weathering and evaporite dissolution in the formation of groundwater chemistry. 
(a)

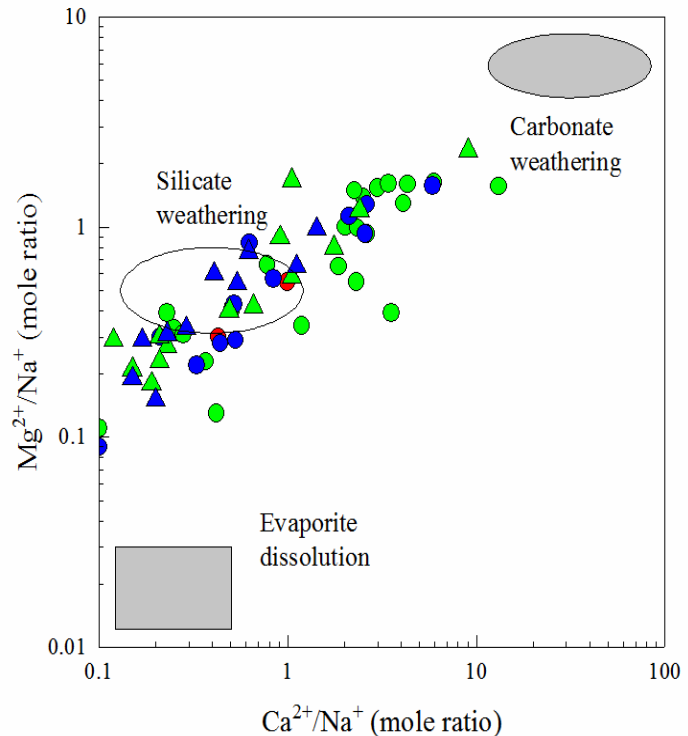

(b)

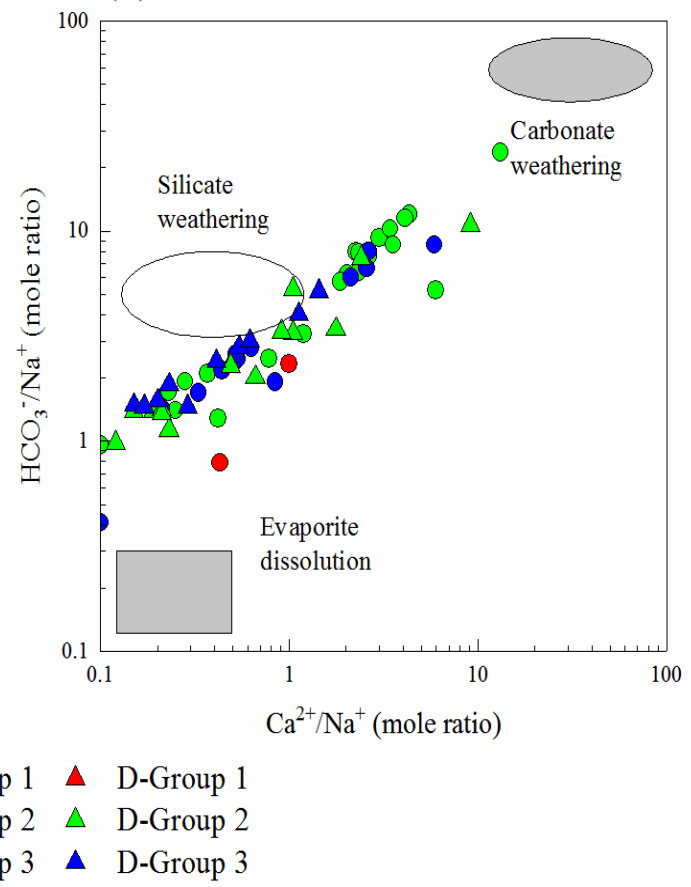

- F-Group 1 a D-Group 1

- F-Group $2 \Delta$ D-Group 2

- F-Group 3 × D-Group 3

Fig. 8 Scatterplots of $\mathrm{Na}^{+}$-normalized $\mathrm{Ca}^{2+}$ versus $\mathrm{Mg}^{2+} / \mathrm{Na}^{+}$(a) and $\mathrm{HCO}_{3}{ }^{-}$(b) to investigate the processes that control groundwater chemistry.

391 The bivariate diagrams of ion concentrations were used to further discriminate the different processes of water-rock interactions (Yong-Hong et al., 2007). $\mathrm{HCO}_{3}{ }^{-}$was the main ionic component of each group (Fig. 3) since it can be naturally introduced by 394 dissolved $\mathrm{CO}_{2}$ in rainwater or carbonate weathering (Marcé et al., 2015). The proportion of dissolved ions is generally determined by the reaction of calcite (Eq. 5) and dolomite (Eq. 6). The molar ratio of $\mathrm{HCO}_{3}{ }^{-} / \mathrm{Ca}^{2+}$ in groundwater is 2 or 4 for

397 exclusive control of calcite or dolomite dissolution, respectively (Liu et al., 2020). Approximately $56.8 \%$ of the flood season samples and $25.9 \%$ of the dry season samples were located between the calcite dissolution line (Fig. 9a, $y=2 x$ ) and dolomite

400 dissolution line $(y=4 x)$, implying the weathering of calcite and dolomite contributed 401 of the most $\mathrm{HCO}_{3}{ }^{-}$in these groundwater samples. The significant positive correlation between $\mathrm{Mg}^{2+}$ and $\mathrm{Ca}^{2+}(\mathrm{r}=0.643)$ in the flood season further confirmed the importance

403 of calcite and dolomite dissolution in groundwater chemistry (Table 4). However, about 
$32.4 \%$ of the flood season samples and $66.7 \%$ of the dry season samples were plotted above the dolomite dissolution line, which may be related to cation exchange or silicate dissolution.

$$
\begin{gathered}
\mathrm{CaCO}_{3}(\text { calcite })+\mathrm{H}_{2} \mathrm{O}+\mathrm{CO} 2 \Leftrightarrow \mathrm{Ca}^{2+}+2 \mathrm{HCO}_{3}{ }^{-} \\
\mathrm{CaMg}\left(\mathrm{CO}_{3}\right)_{2}(\text { dolomite })+2 \mathrm{H}_{2} \mathrm{O}+2 \mathrm{CO}_{2} \Leftrightarrow \mathrm{Ca}^{2+}+\mathrm{Mg}^{2+}+4 \mathrm{HCO}_{3}{ }^{-} \\
\mathrm{CaSO}_{4} \cdot 2 \mathrm{H}_{2} \mathrm{O}(\text { gypsum }) \Leftrightarrow \mathrm{Ca}^{2+}+\mathrm{SO}_{4}{ }^{2-}+2 \mathrm{H}_{2} \mathrm{O}
\end{gathered}
$$

(a)

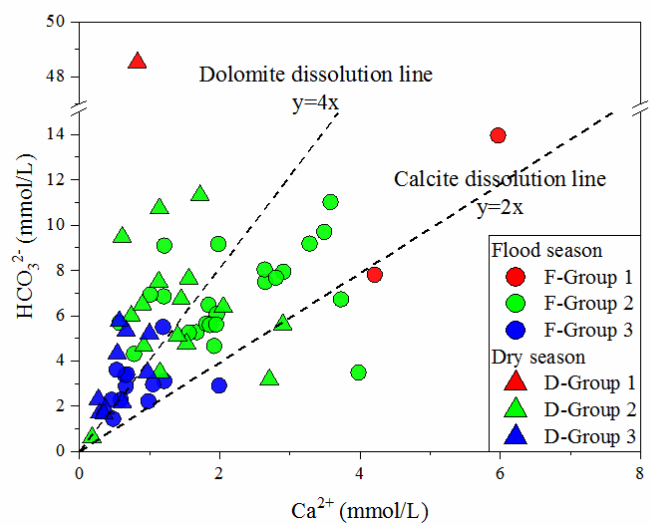

(c)

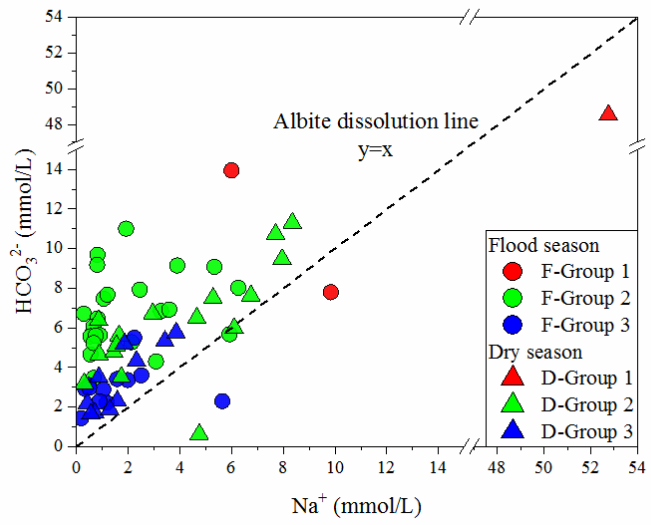

(b)

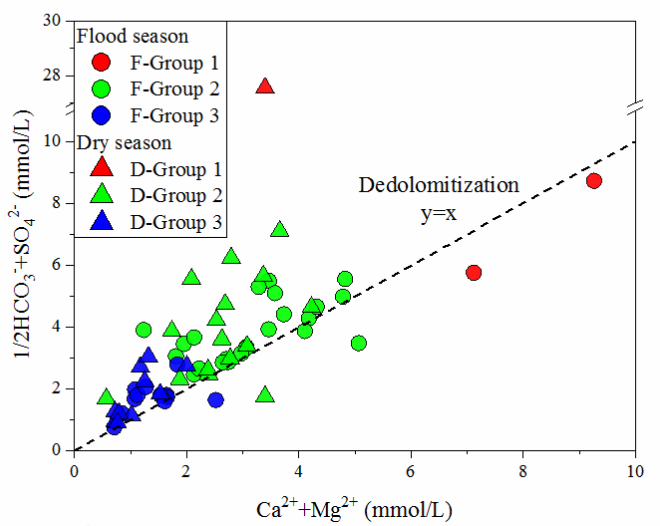

(d)

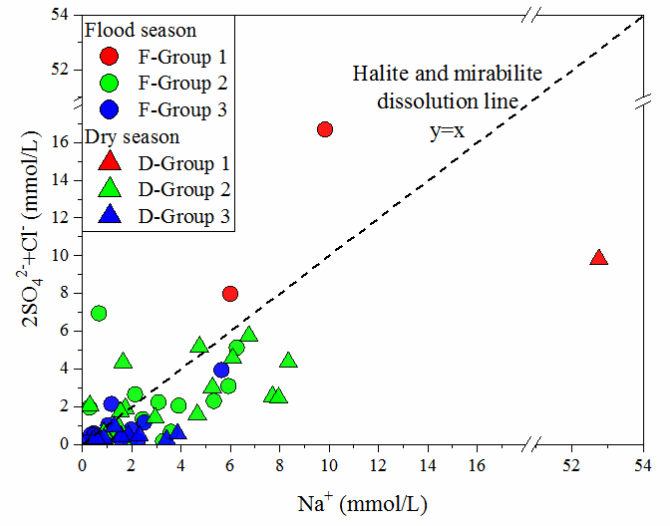

411 Fig. 9 Bivariate diagrams of $\mathrm{HCO}_{3}{ }^{-}$versus $\mathrm{Ca}^{2+}$ (a) to explore the contribution of carbonate to 412 groundwater chemistry; $1 / 2 \mathrm{HCO}_{3}{ }^{-}+\mathrm{SO}_{4}{ }^{2-}$ versus $\mathrm{Ca}^{2+}+\mathrm{Mg}^{2+}$ (b) to examine gypsum dissolution; $413 \mathrm{HCO}_{3}{ }^{-}$versus $\mathrm{Na}^{+}$(c) to investigate the silicate weathering; $\mathrm{SO}_{4}{ }^{2-}$ versus $\mathrm{Na}^{+}$(d) to verify the 414 dissolution of evaporite.

415 In the flood season, a significant correlation existed between $\mathrm{Ca}^{2+}$ and $\mathrm{SO}_{4}{ }^{2-}(\mathrm{r}=0.5)$, 416 indicating gypsum dissolution may have a certain impact on groundwater chemistry. 417 (Eq.7). However, the concentration of $\mathrm{SO}_{4}{ }^{2-}$ was too low to match $\mathrm{Ca}^{2+}$. Therefore, 418 gypsum dissolution may contribute little in the flood season (Yong-Hong et al. 2007). 
419 If $\mathrm{Ca}^{2+}, \mathrm{Mg}^{2+}, \mathrm{SO}_{4}{ }^{2-}$ and $\mathrm{HCO}_{3}{ }^{-}$are derived from the dissolution of calcite, dolomite 420 and gypsum, the charge balance is expressed as $\left(1 / 2 \mathrm{HCO}_{3}{ }^{-}+\mathrm{SO}_{4}{ }^{2-}\right] /\left(\mathrm{Ca}^{2+}+\mathrm{Mg}^{2+}\right)=1$ 421 (Liu et al. 2020). However, most samples (83.8\% collected in the rainy season and 96.3\% 422 collected in the dry season) were located above the 1:1 equilibrium line (Fig. 9b), which 423 indicated insufficient $\mathrm{Ca}^{2+}$ and $\mathrm{Mg}^{2+}$ or excessive $\mathrm{HCO}_{3}{ }^{-}$and $\mathrm{SO}_{4}{ }^{2-}$. Excessive $\mathrm{SO}_{4}{ }^{2-}$ 424 and $\mathrm{HCO}_{3}{ }^{-}$ions was subsequently equalized by $\mathrm{Na}^{+}$, i.e. the conversion of albite to 425 kaolinite releases $\mathrm{HCO}_{3}{ }^{-}$and $\mathrm{Na}^{+}$(Eq. 8). In the dry season, $\mathrm{HCO}_{3}{ }^{-}$was significantly 426 correlated with $\mathrm{Na}^{+}(\mathrm{r}=0.981)$ and $\mathrm{Mg}^{2+}(\mathrm{r}=0.716)$, and most of the dry season samples 427 were close to the albite dissolution line (Fig. 9c). Thus, the silicate weathering played 428 an important role in the groundwater chemistry in the flood season and the dry season 429 (Yong-Hong et al. 2007). $2 \mathrm{NaAlSi}_{3} \mathrm{O}_{8}($ albite $)+11 \mathrm{H}_{2} \mathrm{O}+2 \mathrm{CO}_{2} \Leftrightarrow \mathrm{Al}_{2} \mathrm{Si}_{2} \mathrm{O}_{5}(\mathrm{OH})_{4}($ kaolinite $)+2 \mathrm{Na}^{+}+2 \mathrm{HCO}_{3}^{-}+\mathrm{H}_{4} \mathrm{SiO}_{4}$ (8) 431

$$
\begin{gathered}
\mathrm{NaCl}(\text { halite }) \rightarrow \mathrm{Na}^{+}+\mathrm{Cl}^{-} \\
\mathrm{Na}_{2} \mathrm{SO}_{4} \cdot 10 \mathrm{H}_{2} \mathrm{O}(\text { mirabilite }) \Leftrightarrow 2 \mathrm{Na}^{+}+\mathrm{SO}_{4}{ }^{2-}+10 \mathrm{H}_{2} \mathrm{O}
\end{gathered}
$$

434 The contribution of halite and mirabilite dissolution can be confirmed by the scatterplot 435 of $\left(2 \mathrm{SO}_{4}{ }^{2-}+\mathrm{Cl}^{-}\right)$versus $\mathrm{Na}^{+}$(Sarin et al., 1989) (Fig. 9d). As shown in Fig. 9d, 436 approximately $75.7 \%$ of the samples in the flood season and $81.5 \%$ in the dry season 437 fell below the $\mathrm{y}=\mathrm{x}$ line, signifying that $\mathrm{Na}^{+}$in groundwater may have other sources 438 such as cation exchange or silicate dissolution in addition to evaporite dissolution.

439 Table 4 Pearson correlation matrix between hydrochemical parameters of groundwater samples in

\begin{tabular}{|c|c|c|c|c|c|c|c|c|c|}
\hline & $\mathrm{Ca}^{2+}$ & $\mathrm{Mg}^{2+}$ & $\mathrm{Na}^{+}$ & $\mathrm{K}^{+}$ & $\mathrm{HCO}_{3}{ }^{-}$ & $\mathrm{SO}_{4}^{2-}$ & $\mathrm{NO}_{3}{ }^{-}$ & $\mathrm{Cl}^{-}$ & TDS \\
\hline $\mathrm{Ca}^{2+}$ & & $0.634 * *$ & 0.191 & 0.161 & $0.737 * *$ & $0.5^{* *}$ & $0.426 * *$ & $0.462 * *$ & $0.389 * *$ \\
\hline $\mathrm{Mg}^{2+}$ & 0.328 & & $0.614 * *$ & 0.089 & $0.711 * *$ & $0.585^{* *}$ & $0.527 * *$ & $0.661 * *$ & $0.647 * *$ \\
\hline $\mathrm{Na}^{+}$ & -0.076 & $0.651 * *$ & & 0.101 & $0.385^{* *}$ & $0.676^{* *}$ & $0.372 * *$ & $0.733 * *$ & $0.806 * *$ \\
\hline $\mathrm{K}^{+}$ & $0.609 * *$ & $0.52 * *$ & 0.098 & & 0.213 & 0.017 & 0.057 & 0.078 & 0.071 \\
\hline $\mathrm{HCO}_{3}^{-}$ & 0.05 & $0.716 * *$ & $0.981 * *$ & 0.204 & & 0.264 & 0.269 & 0.214 & 0.308* \\
\hline $\mathrm{SO}_{4}{ }^{2-}$ & 0.208 & $0.759 * *$ & $0.786^{* *}$ & 0.25 & $0.755 * *$ & & $0.36 * *$ & $0.734 * *$ & $0.771^{* * *}$ \\
\hline $\mathrm{NO}_{3}^{-}$ & $0.355 *$ & 0.247 & $0.413 * *$ & 0.147 & $0.416 * *$ & 0.248 & & $0.412 * *$ & $0.425 * *$ \\
\hline
\end{tabular}
440 the flood season (the right upper part) and in the dry season (the left lower part) 
*: Correlation is significant at $\mathrm{p}<0.05$ level (2-tailed).

443 Cation exchange was considered a significant process to control groundwater chemistry 444 (Schoeller 1967). The chloro-alkaline indices (i.e., CAI1 and CAI2) were used to 445 interpret the occurrence of cation exchange in groundwater (Eq.11 and Eq.12) (Yong446 Hong et al. 2007):

$$
\begin{gathered}
C A I 1=\frac{\mathrm{Cl}^{-}-\left(\mathrm{Na}^{+}+\mathrm{K}^{+}\right)}{\mathrm{Cl}^{-}} \\
C A I 2=\frac{\mathrm{Cl}-\left(\mathrm{Na}^{+}+\mathrm{K}^{+}\right)}{\mathrm{SO}_{4}{ }^{2-}+\mathrm{HCO}_{3}{ }^{-}+\mathrm{CO}_{3}{ }^{2-}+\mathrm{NO}_{3}{ }^{-}}
\end{gathered}
$$

449 where all the ionic units are meq/L. Approximately $94.6 \%$ of the flood season samples 450 in and $96.3 \%$ of the dry season samples exhibited negative CAI1 and CAI2 values, 451 which suggested that cation exchange between $\mathrm{Ca}^{2+}$ and $\mathrm{Mg}^{2+}$ in groundwater and $\mathrm{Na}^{+}$ 452 and $\mathrm{K}^{+}$in aquifers was prevalent in the study area. Again, this indicated that cation 453 exchange played an important role for source of $\mathrm{Na}^{+}$in groundwater.

\section{$454 \quad 4.3$ Quantification of source contributions to dissolved solutes}

455 The calculation results of the contribution of different sources to the dissolved solutes 456 in groundwater in the two seasons were shown in Table 5.

Table 5 Contributions of different sources to the dissolved solutes in groundwater.

\begin{tabular}{ccccccc}
\hline & & $\begin{array}{c}\text { Atmospheric } \\
\text { Input }(\%)\end{array}$ & $\begin{array}{c}\text { Anthropogenic } \\
\text { Input (\%) }\end{array}$ & $\begin{array}{c}\text { Evaporite } \\
\text { Dissolution (\%) }\end{array}$ & $\begin{array}{c}\text { Silicate } \\
\text { Weathering (\%) }\end{array}$ & $\begin{array}{c}\text { Carbonate } \\
\text { Weathering (\%) }\end{array}$ \\
\hline \multirow{3}{*}{ Flood season } & Min & 0.50 & 0.27 & 0.33 & 0.52 & 0.00 \\
& Max & 9.26 & 39.40 & 88.96 & 92.82 & 71.77 \\
& Mean \pm SD & $2.3 \pm 1.5$ & $5.0 \pm 7.1$ & $19.3 \pm 21.4$ & $42.8 \pm 27.3$ & $30.6 \pm 27.1$ \\
Dry season & Min & 0.60 & 0.00 & 2.24 & 1.28 & 0.00 \\
& Max & 25.05 & 26.33 & 69.59 & 87.19 & 53.50 \\
& Mean \pm SD & $9.1 \pm 6.4$ & $3.4 \pm 5.2$ & $20.3 \pm 15.9$ & $56.6 \pm 23.2$ & $10.7 \pm 15.4$
\end{tabular}


458

The contribution of atmospheric inputs to solutes in groundwater was measured by the $\mathrm{Cl}^{-}$content in rainwater (Noh et al. 2009). With reference to the East Asia Acid Rain Network, the average concentration of $\mathrm{Cl}^{-}$in rainwater was 0.81 and $2.15 \mathrm{mg} / \mathrm{L}$ in the dry season and the flood season, respectively. The mean contribution of atmospheric inputs to dissolved solutes in the dry season was $9.1 \% \pm 6.4 \%$, which was significantly higher than that in the flood season $(2.3 \% \pm 1.5 \%)$. This result was consistent with previous studies in arid areas ( $\mathrm{Li}$ et al. 2019b; Xiao et al. 2015). This phenomenon can be explained by two potential reasons: (i) compared with the flood season, the rainwater in the dry season had a higher ion concentration, which dominated the contribution of atmospheric inputs to the solutes; (ii) the flux of atmospheric inputs was larger in the flood season, but it may have time lag to reach the aquifer because of the thick vadose zone (Li et al. 2017). However, more frequent sampling is required to clarify this.

Table 6 Chemical composition of rainwater (Data from East Asia Acid Rain Network).

\begin{tabular}{cccccccc}
\hline & \multicolumn{7}{c}{ Ion concentration $(\mathrm{mg} / \mathrm{L})$} \\
\cline { 2 - 7 } & $\mathrm{SO}_{4}{ }^{2-}$ & $\mathrm{NO}_{3}{ }^{-}$ & $\mathrm{Cl}^{-}$ & $\mathrm{Na}^{+}$ & $\mathrm{K}^{+}$ & $\mathrm{Ca}^{2+}$ & $\mathrm{Mg}^{2+}$ \\
\hline Flood season & 2.50 & 0.79 & 0.81 & 0.45 & 0.47 & 1.72 & 0.24 \\
Dry season & 4.12 & 3.85 & 2.15 & 0.99 & 0.69 & 8.44 & 1.64 \\
\hline
\end{tabular}

The anthropogenic impacts on groundwater chemistry can be characterized by the concentration of $\mathrm{NO}_{3}{ }^{-}$and $\mathrm{H}_{2} \mathrm{PO}_{4}{ }^{-}$in the water (Xiao 2016). In this study, $\mathrm{H}_{2} \mathrm{PO}_{4}{ }^{-}$was not considered because its concentration was below detection limit. The average contribution of anthropogenic inputs to solutes in groundwater was $5.0 \% \pm 7.1 \%$ and $3.4 \% \pm 5.2 \%$ in the flood season and the dry season, respectively. Although the overall contribution of anthropogenic inputs to groundwater was minor, it is the dominant source of solutes for some groundwater. For example, for sample F14 with $\mathrm{NO}_{3}{ }^{-}$ concentration up to $165.9 \mathrm{mg} / \mathrm{L}$, the average contribution value of anthropogenic inputs 
reached 39\%. The groundwater nitrate from human activities may include $\mathrm{NO}_{3}{ }^{-}$ fertilizer, $\mathrm{NH}_{4}{ }^{+}$fertilizer, manure and septic waste (Zhang et al. 2018). Due to excessive fertilizer application in most regions, the storage of $\mathrm{NO}_{3}{ }^{-}$is large in the soil and rocks (Fewtrell and Lorna 2004). As such, precipitation had insignificant dilution effect on $\mathrm{NO}_{3}{ }^{-}$in groundwater (Table 2), and even increased the groundwater $\mathrm{NO}_{3}{ }^{-}$contents in the flood season (Ji et al. 2020).

The contributions of evaporite dissolution, silicate and carbonate weathering to dissolved solutes were calculated according to the flowchart in Fig.2. For evaporite, we only considered the contributions of gypsum and halite dissolution to solutes because of no evidence for the existence of pyrite (Larssen et al. 1999; Li et al. 2019b) and rare sulfuric acid in precipitation on the Loess plateau (Table 5). The average contribution of evaporite dissolution was $19.7 \% \pm 19.1 \%$ in the flood season, which was slightly lower than that in the dry season.

The contribution of silicate weathering to dissolved solutes varied from $1 \%$ to $93 \%$ (average $42.8 \% \pm 27.3 \%$ ) and from 1.28 to 87.19 (average $56.6 \% \pm 23.2 \%$ ) in the flood season and the dry season, respectively, while for carbonate, the corresponding values were in the range of $30.6 \% \pm 27.1 \%$ and $10.7 \% \pm 15.4 \%$, respectively.

The order of the contribution of different sources to solutes in the flood season was silicate $>$ carbonate $>$ evaporite $>$ anthropogenic input $>$ atmospheric input, while the contribution in the dry season was silicate $>$ evaporite $>$ carbonate $>$ atmospheric input $>$ anthropogenic input. Obviously, silicate weathering was the major contributor to dissolved solutes in groundwater in the Loess Plateau. This finding was consistent with the results obtained by (Hua et al. 2019) and (Kou et al. 2019) in studying the source of groundwater solutes in the Loess Plateau. However, compared with other regions, the predominant source of groundwater chemistry was different due to different geological 
504 factors and climatic conditions. For instance, carbonate weathering was the main source 505 of solutes in the groundwater of the Bishuiyan subterranean basin in Guangxi (Jiang et 506 al. 2020), while evaporite dissolution contributed most in the Tarim River Basin (Xiao 507 et al. 2015).

\section{Conclusions}

509 Water quality is an important indicator for ensuring biological growth and socio510 economic development, especially in arid regions such as the Chinese Loess Plateau. 511 In this study, the hydrochemical characteristics of dissolved major elements in 512 groundwater collected from the Loess Plateau were studied. The contents of $\mathrm{Na}^{+}, \mathrm{Mg}^{2+}$,

$513 \mathrm{HCO}_{3}{ }^{-}$, and $\mathrm{SO}_{4}{ }^{2-}$ in groundwater during the dry season were greater than those during 514 the flood season, while the contents of $\mathrm{K}^{+}, \mathrm{Ca}^{2+}, \mathrm{Cl}^{-}$, and $\mathrm{NO}_{3}{ }^{-}$were lower than those 515 during the flood season. HCA and correlation analysis coupled with conventional 516 hydrochemical plots suggests that minerals dissolution and cation exchange are the key 517 factors in controlling groundwater chemistry. Moreover, anthropogenic activities (e.g., 518 agricultural activities) also have a certain impact on the formation of dissolved solutes 519 in groundwater, especially during the flood season. Most of the groundwater $(95 \%$ in 520 the flood season and $96 \%$ in the dry season) was suitable for drinking, and overall water 521 quality was acceptable for irrigation. The calculation results based on the forward 522 model showed that the order of the contribution of different sources to dissolved solutes 523 in the flood season was silicate $>$ carbonate $>$ evaporite $>$ anthropogenic input $>$ 524 atmospheric input, while in the dry season was silicate $>$ evaporite $>$ carbonate $>$ 525 atmospheric input $>$ anthropogenic input.

\section{Data availability}

527 The datasets used and/or analyzed during this study are included in this published article. 


\section{References}

Aghababazadeh R, Mirhabibi AR, Rand B, Banijamali S, Pourasad J, Ghahari M (2016) Synthesis and characterization of nanocrystalline titanium nitride powder from rutile and anatase as precursors. Water Science 30:19-40.

Ahada CPS, Suthar S (2018) Assessing groundwater hydrochemistry of Malwa Punjab, India. Arab. J. Geosci. 11:17.

Alarcon-Herrera MT, Bundschuh J, Nath B, Nicolli HB, Gutierrez M, Reyes-Gomez VM, Nuñez D, Martín-Dominguez IR (2013) Co-occurrence of arsenic and fluoride in groundwater of semiarid regions in Latin America: Genesis, mobility and remediation. J. Hazard. Mater. 262:960969.

Banoeng-Yakubo B, Yidana SM, Nti E (2009) An evaluation of the genesis and suitability of ground water for irrigation in the Volta Region, Ghana. Environ. Geol. 57:1005-1010.

Bernal S, Lupon A, Ribot M, Sabater F, Martí E (2015) Riparian and in-stream controls on nutrient concentrations and fluxes in a headwater forested stream. Biogeosciences 12:1941-1954.

Brindha K, Rajesh R, Murugan R, Elango L (2011) Fluoride contamination in groundwater in parts of Nalgonda District, Andhra Pradesh, India. Environ. Monit. Assess. 172:481-492.

Brindha K, Jagadeshan G, Kalpana L, Elango L (2016) Fluoride in weathered rock aquifers of southern India: managed aquifer recharge for mitigation. Environ. Sci. Pollut. Res. 23:8302-8316.

Famiglietti JS (2014) The global groundwater crisis. Nat. Clim. Chang. 4:945-948.

Fewtrell L (2004) Drinking-Water Nitrate, Methemoglobinemia, and Global Burden of Disease: A Discussion. Environ. Health Perspect. 112:1371-1374.

Zaidi FK, Nazzal Y, Jafri MK, Naeem M, Ahmed I (2015) Reverse ion exchange as a major process controlling the groundwater chemistry in an arid environment: a case study from northwestern Saudi Arabia. Environ. Monit. Assess. 187:607.

Zaidi FK, Nazzal Y, Jafri MK, Naeem M, Ahmed I (2015) Reverse ion exchange as a major process controlling the groundwater chemistry in an arid environment: a case study from northwestern Saudi Arabia. Environ. Monit. Assess. 187:607.

Gaillardet J, Dupré B, Allègre CJ (1995) A global geochemical mass budget applied to the Congo basin rivers: Erosion rates and continental crust composition. Geochim. Cosmochim. Acta 59:34693485.

Gates JB, Scanlon BR, Mu X, Lu Z (2011) Impacts of soil conservation on groundwater recharge in the semi-arid Loess Plateau, China. Hydrogeol. J. 19:865-875.

Gibbs RJ (1970) Mechanisms Controlling World Water Chemistry. Science 170:1088-1090.

Guo X, Zuo R, Wang J, Meng L, Teng Y, Shi R, Gao X, Ding F (2019) Hydrogeochemical Evolution of Interaction Between Surface Water and Groundwater Affected by Exploitation. Ground water 57:430-442.

Hua K, Jun X, Li S (2019) Analysis of hydrochemical characteristics and their controlling factors in the Fen River of China. Sust. Cities Soc. 52:101827. 
Huang T, Pang Z, Liu J, Ma J, Gates J (2017) Groundwater recharge mechanism in an integrated tableland of the Loess Plateau, northern China: insights from environmental tracers. Hydrogeol. J. 25:2049-2065.

Huang Y, Chang Q, Li Z (2018) Land use change impacts on the amount and quality of recharge water in the loess tablelands of China. Sci. Total Environ. 628-629:443-452.

Ismail AH, Shareef MA, Alatar FM (2019) Hydrochemistry of Groundwater and its Suitability for Drinking and Irrigation in Baghdad, Iraq. Environ. Process. 6:543-560

Ismail AH, Shareef MA, Mahmood W (2018) Hydrochemical characterization of groundwater in Balad district, Salah Al-Din Governorate, Iraq. J. Groundwater Sci. Eng. 6:67-83.

Griffiths JC (1974) Statistics and Data Analysis in Geology: J.C. Davis, 1973. Wiley, Chichester, 550 pp., U.S. \$18.50. Earth-Sci. Rev. 10:145-146.

Jasechko S, Perrone D, Befus KM, Bayani Cardenas M, Ferguson G, Gleeson T, Luijendijk E, McDonnell JJ, Taylor RG, Wada Yoshihide, Kirchner JW (2017) Global aquifers dominated by fossil groundwaters but wells vulnerable to modern contamination. Nat. Geosci. 10:425-429.

Ji W, Huang Y, Li B, Hopkins DW, Liu W, Li Z (2020) Legacy nitrate in the deep loess deposits after conversion of arable farmland to non - fertilized land uses for degraded land restoration. Land Degrad. Dev. 31:1355-1365.

Jiang P, Yu G, Zhang Q, Zou Y, Tang Q, Kang Z, Sytharith P, Xiao H (2020) Chemical weathering and $\mathrm{CO} 2$ consumption rates of rocks in the Bishuiyan subterranean basin of Guangxi, China. Sci Rep 10:11677.

Kou Y, Li Z, Hua K, Li Z (2019) Hydrochemical Characteristics, Controlling Factors, and Solute Sources of Streamflow and Groundwater in the Hei River Catchment, China. Water 11:2293.

López-Alvis J, Carrera-Hernández JJ, Levresse G, Nieto-Samaniego ÁF (2019) Assessment of groundwater depletion caused by excessive extraction through groundwater flow modeling: the Celaya aquifer in central Mexico. Environ. Earth Sci. 78:482-.

Larssen T, Seip HM, Semb A, Mulder J, Eilertsen O (1999) Acid deposition and its effects in China: an overview. Environ. Sci. Policy 2:9-24.

Li P, Zhang Y, Yang N, Jing L, Yu P (2016) Major ion chemistry and quality assessment of groundwater in and around a mountainous tourist town of China. Expo Health 8:239-252. https://doi.org/10.1007/s12403-016-0198-6.

Li P, Tian R, Xue C, Wu J (2017a) Progress, opportunities and key fields for groundwater quality research under the impacts of human activities in China with a special focus on western China. Environ Sci Pollut Res 24:13224-13234.

Li P, He X, Li Y, Xiang G (2019a) Occurrence and health implication of fluoride in groundwater of loess aquifer in the Chinese loess plateau: a case study of Tongchuan, Northwest China. Expo Health 11:95-107.

Li Z, Zheng Fl, Liu WZ, Flanagan DC (2010) Spatial distribution and temporal trends of extreme temperature and precipitation events on the Loess Plateau of China during 1961-2007. Quat. Int. 226:92-100.

Li Z, Chen X, Liu W, Si B (2017b) Determination of groundwater recharge mechanism in the deep loessial unsaturated zone by environmental tracers. Sci. Total Environ. 586:827-835. 
Li Z, Coles AE, Xiao J (2019b) Groundwater and streamflow sources in China's Loess Plateau on catchment scale. Catena 181:104075.

Li Z, Xiao J, Evaristo J, Li Z (2019c) Spatiotemporal variations in the hydrochemical characteristics and controlling factors of streamflow and groundwater in the Wei River of China. Environ. Pollut. 254:113006.

Liu F, Wang S, Yeh TCJ, Zhen P, Wang L, Shi L (2020) Using multivariate statistical techniques and geochemical modelling to identify factors controlling the evolution of groundwater chemistry in a typical transitional area between Taihang Mountains and North China Plain. Hydrol. Process. 34:1888-1905.

Liu X, Wang Y, Li S (2018) The root cause of groundwater pollution and its treatment analysis. Environment \& Development, 030:47-48. (in Chinese)

Loh YSA, Akurugu BA, Manu E, Abdul-Samed A (2019) Assessment of groundwater quality and the main controls on its hydrochemistry in some Voltaian and basement aquifers, northern Ghana. Groundwater for Sustainable Development, 10:100296.

Marcé R, Obrador B, Morguí JA, Lluís Riera J, López P, Armengol J (2015) Carbonate weathering as a driver of $\mathrm{CO}_{2}$ supersaturation in lakes. Nat. Geosci. 8:107-111.

Masoud MHZ, Basahi JM, Rajmohan N (2018) Impact of flash flood recharge on groundwater quality and its suitability in the Wadi Baysh Basin, Western Saudi Arabia: an integrated approach. Environ. Earth Sci. 77:395.

Noh H, Huh Y, Qin J, Ellis A (2009) Chemical weathering in the Three Rivers region of Eastern Tibet. Geochim. Cosmochim. Acta 73:1857-1877.

Sarin MM, Krishnaswami S, Dilli K, Somayajulu BLK, Moore WS (1989) Major ion chemistry of the Ganga- Brahmaputr river system: Weathering processes and fluxes to the Bay of Bengal. Geochim. Cosmochim. Acta 53:997-1009.

Schoeller H (1967) Hydrodynamique dans le karst. Chron. Hydrogéol. 10:7-21.

Subba Rao N (2020) Spatial distribution of quality of groundwater and probabilistic non-carcinogenic risk from a rural dry climatic region of South India. Environ. Geochem. Health. https://doi.org/10.1007/s10653-020-00621-3.

Subba Rao N, Sunitha B, Adimalla N, Chaudhary M (2020) Quality criteria for groundwater use from a rural part of Wanaparthy District, Telangana State, India, through ionic spatial distribution (ISD), entropy water quality index (EWQI) and principal component analysis (PCA). Environ. Geochem. Health 42:579-599.

Wang J, Liu G, Liu H, Lam PKS (2017) Multivariate statistical evaluation of dissolved trace elements and a water quality assessment in the middle reaches of Huaihe River, Anhui, China. Sci. Total Environ. 583:421-431.

Wu J, Sun Z (2016) Evaluation of Shallow Groundwater Contamination and Associated Human Health Risk in an Alluvial Plain Impacted by Agricultural and Industrial Activities, Mid-west China. Expo Health. 8:311-329.

Wu L, Huh Y, Qin J, Du G, Lee SVD (2005) Chemical weathering in the Upper Huang He (Yellow River) draining the eastern Qinghai-Tibet Plateau. Geochim. Cosmochim. Acta 69:279-5294. 


\section{Ethics declarations} 17:331-342. 9. Geophys. 39:715-727.

\section{Funding} (2452020002).

\section{Authors' contributions}

\section{Confict of interests}

Xiao J, Jin Z, Wang J, Zhang F (2015) Hydrochemical characteristics, controlling factors and solute sources of groundwater within the Tarim River Basin in the extreme arid region, NW Tibetan Plateau. Quat. Int. 380-381:237-246.

Xiao J, Jin ZD, Zhang F (2016) Spatial characteristics and controlling factors of chemical weathering of loess in the dry season in the middle Loess Plateau, China. Hydrol. Process. 30:4855-4869.

Yong-Hong SU, FENG Q, ZHU G-F, SI J-H, ZHANG Y-W (2007) Identification and Evolution of Groundwater Chemistry in the Ejin Sub-Basin of the Heihe River, Northwest China. Pedosphere

Yu Y, Jin Z, Chu G, Zhang J, Wang Y, Zhao Y (2020) Effects of valley reshaping and damming on surface and groundwater nitrate on the Chinese Loess Plateau. J. Hydrol. 584:124702.

Zanotti C, Rotiroti M, Fumagalli L, Stefania GA, Canonaco F, Stefenelli G, Prévôt ASH, Leoni B, Bonomi T (2019) Groundwater and surface water quality characterization through positive matrix factorization combined with GIS approach. Water Res. 159:122-134.

Zhang Q, Wang H, Long W (2018) Tracing nitrate pollution sources and transformations in the overexploited groundwater region of North China using stable isotopes. J. Contam. Hydrol. 218:1-

Zhu Y, Jia X, Shao M (2018) Loess Thickness Variations Across the Loess Plateau of China. Surv.

This study is jointly funded by National Natural Science Foundation of China (42002265 \& 42071043), and the Talent Program of Northwest A\&F University

Shujian Li: Conceptualization, Methodology, Software, Investigation, Formal analysis, Writing - Original Draft. He Su: Writing - Review \& Editing, Funding acquisition. Zhi Li: Conceptualization, Methodology, Resources, Writing-Review \& Editing, Data Curation, Validation, Supervision, Funding acquisition. 
676 The authors claim no conflicts of interest.

\section{Ethical approval}

678 Not applicable

679 Consent to participate

680 Not applicable

\section{Consent to publish}

682 Not applicable 


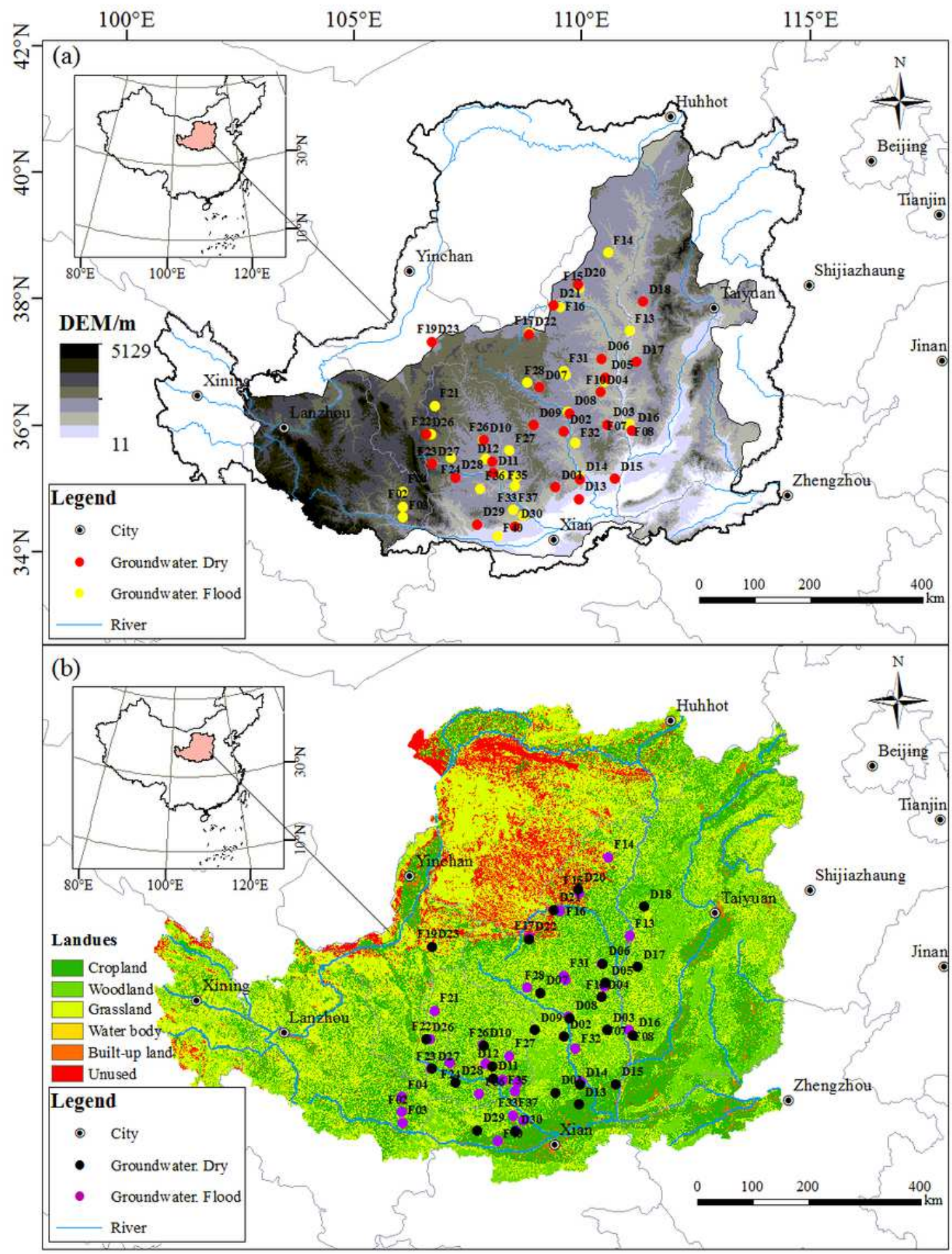

\section{Figure 1}

(a) Geographical location of the Loess Plateau and groundwater sampling sites. (b) Land use of the Loess Plateau. Note: The designations employed and the presentation of the material on this map do not imply the expression of any opinion whatsoever on the part of Research Square concerning the legal 
status of any country, territory, city or area or of its authorities, or concerning the delimitation of its frontiers or boundaries. This map has been provided by the authors.

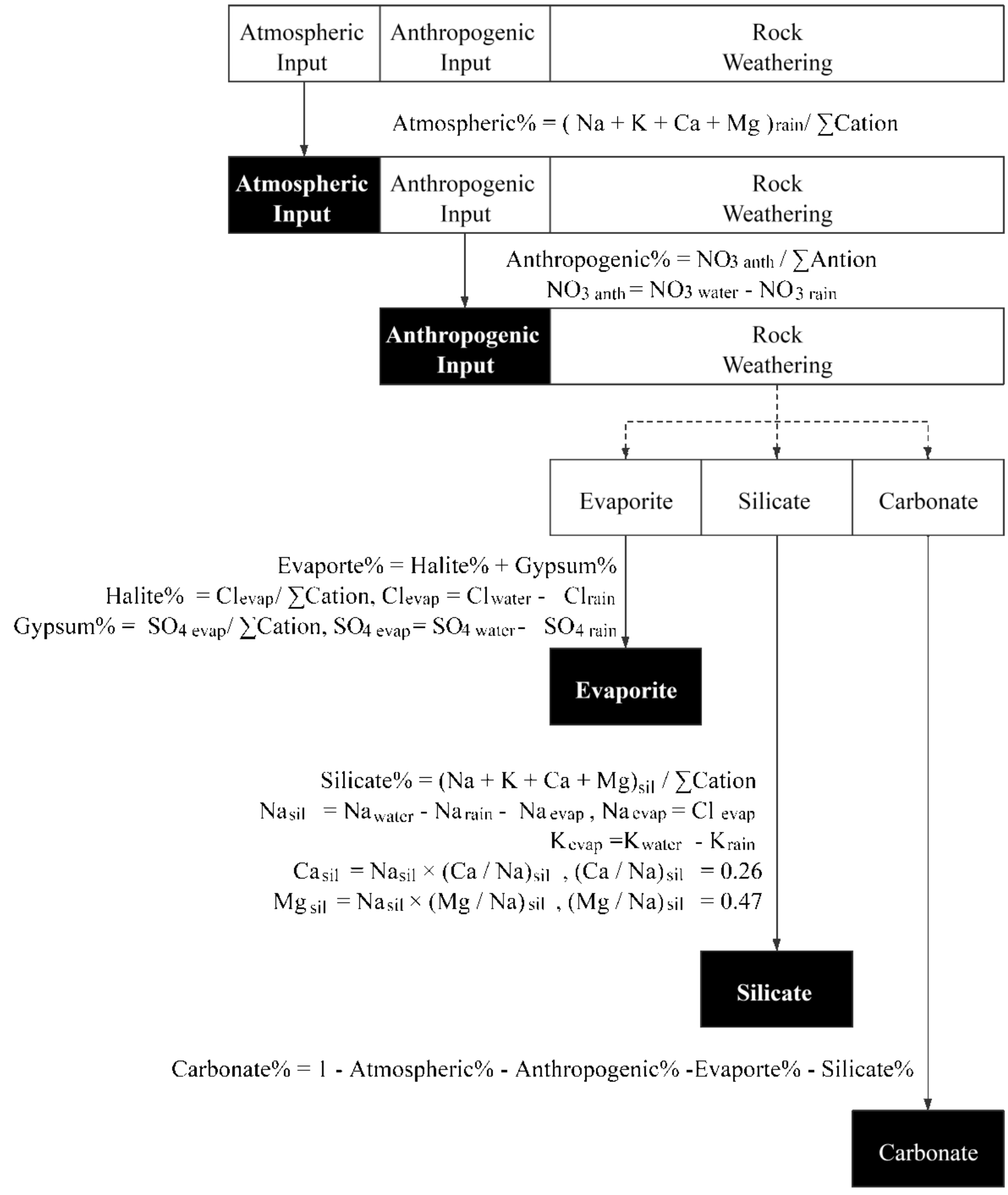

Figure 2

Overall framework of forward model for quantification of source contribution to dissolved solutes in groundwater. 

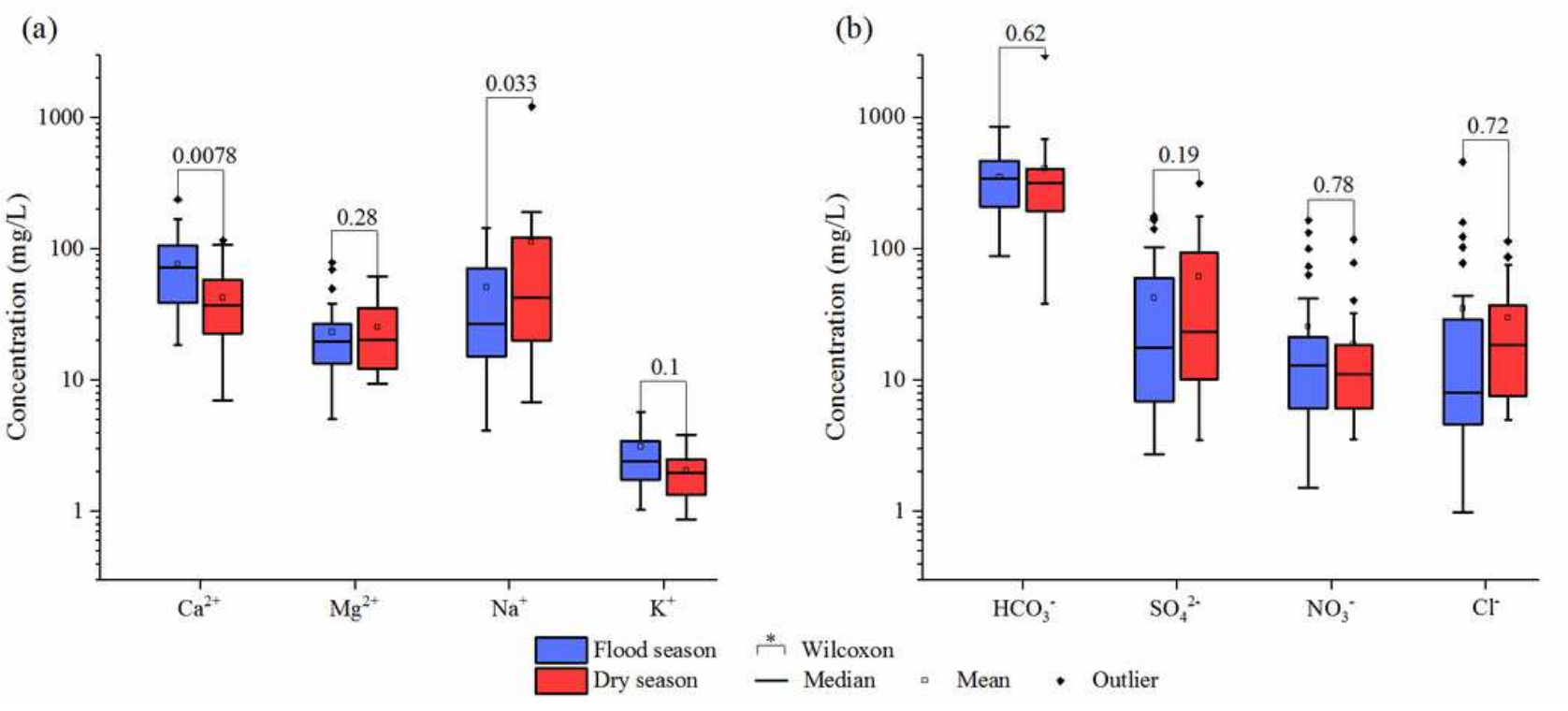

Figure 3

Box plots showing variations of major cations (a) and anions (b) concentrations in groundwater in two different seasons ( $p<0.05$ means significant difference).
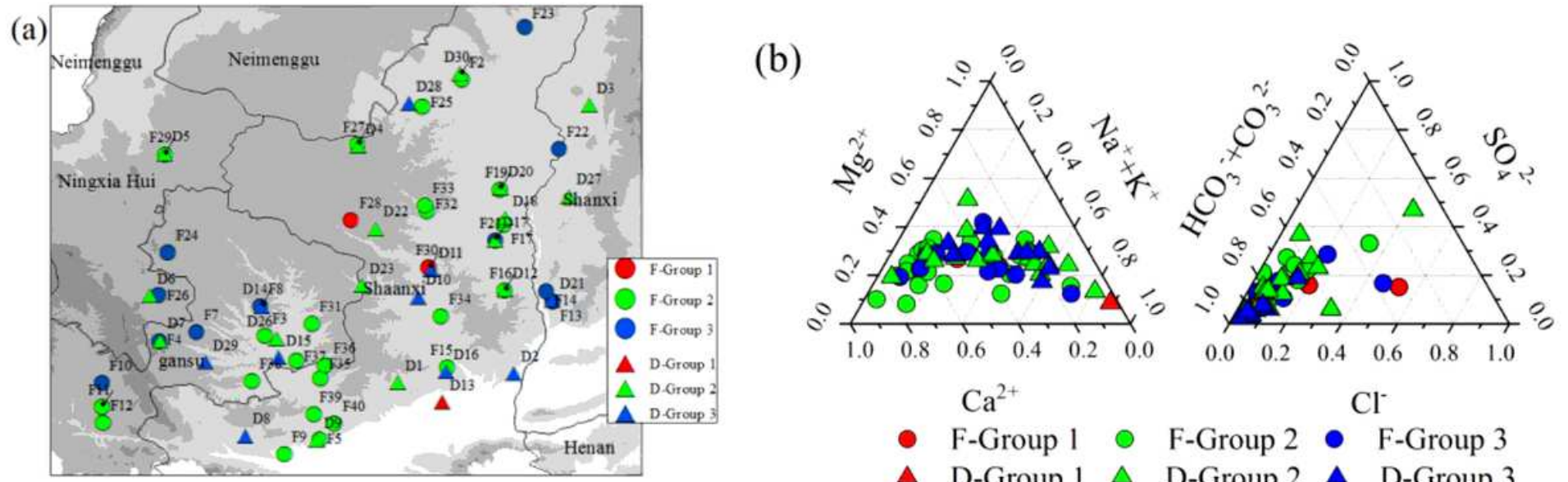

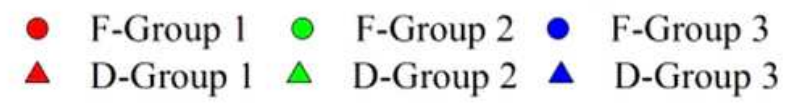

\section{Figure 4}

Spatial distribution (a) and ternary diagrams (b) of the six clusters (F-Group 1-3, D-Group1-3) in the study area. Note: The designations employed and the presentation of the material on this map do not imply the expression of any opinion whatsoever on the part of Research Square concerning the legal status of any country, territory, city or area or of its authorities, or concerning the delimitation of its frontiers or boundaries. This map has been provided by the authors. 
(a)

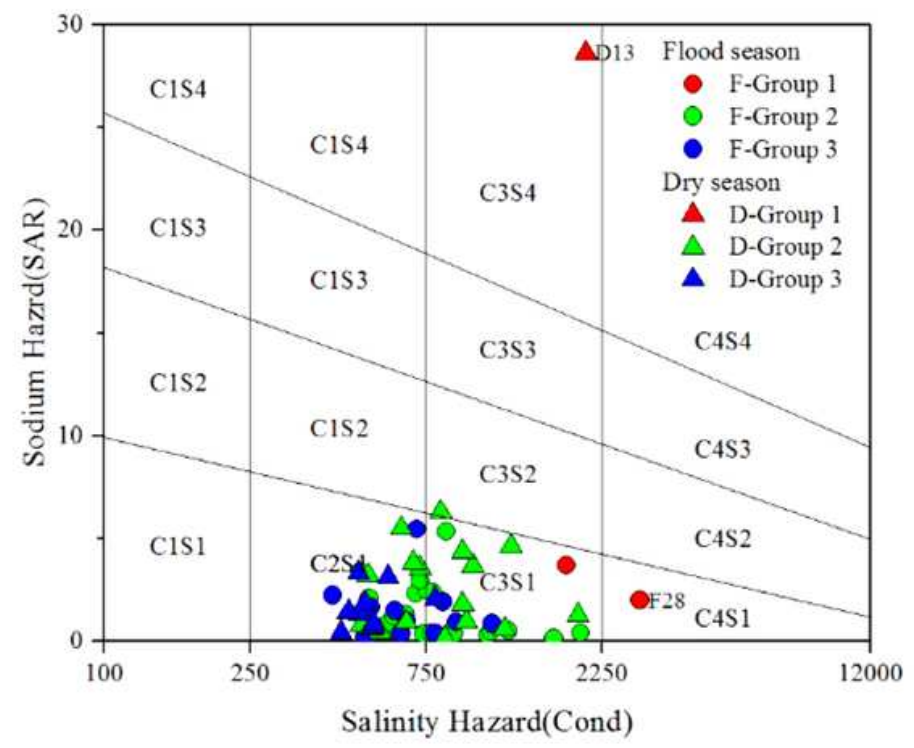

(b)

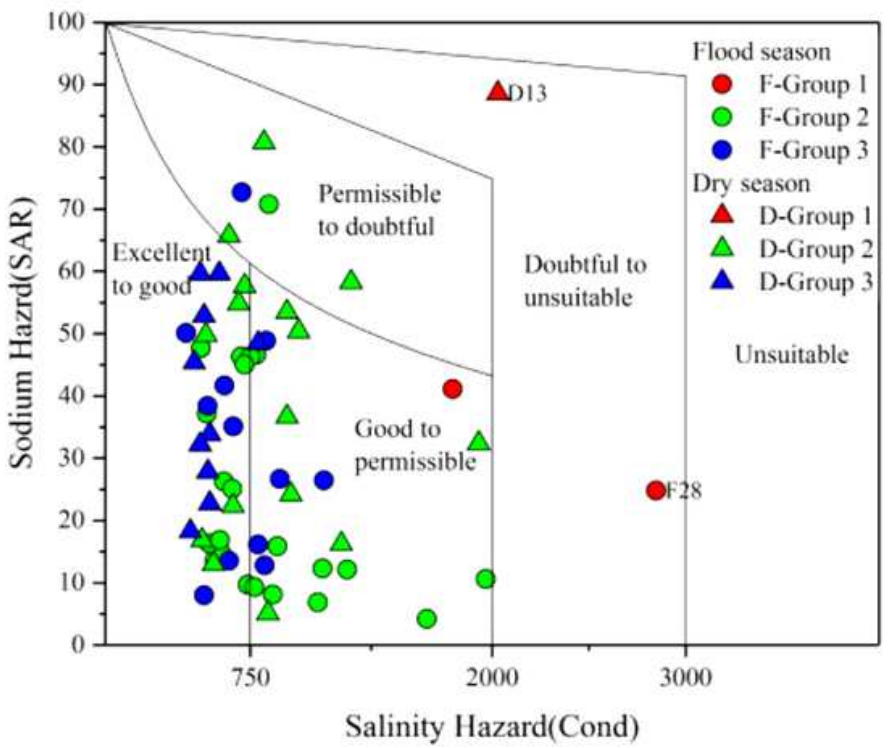

\section{Figure 5}

USSL diagram (a) and Wilcox diagram (b) to investigate the quality of irrigation water.

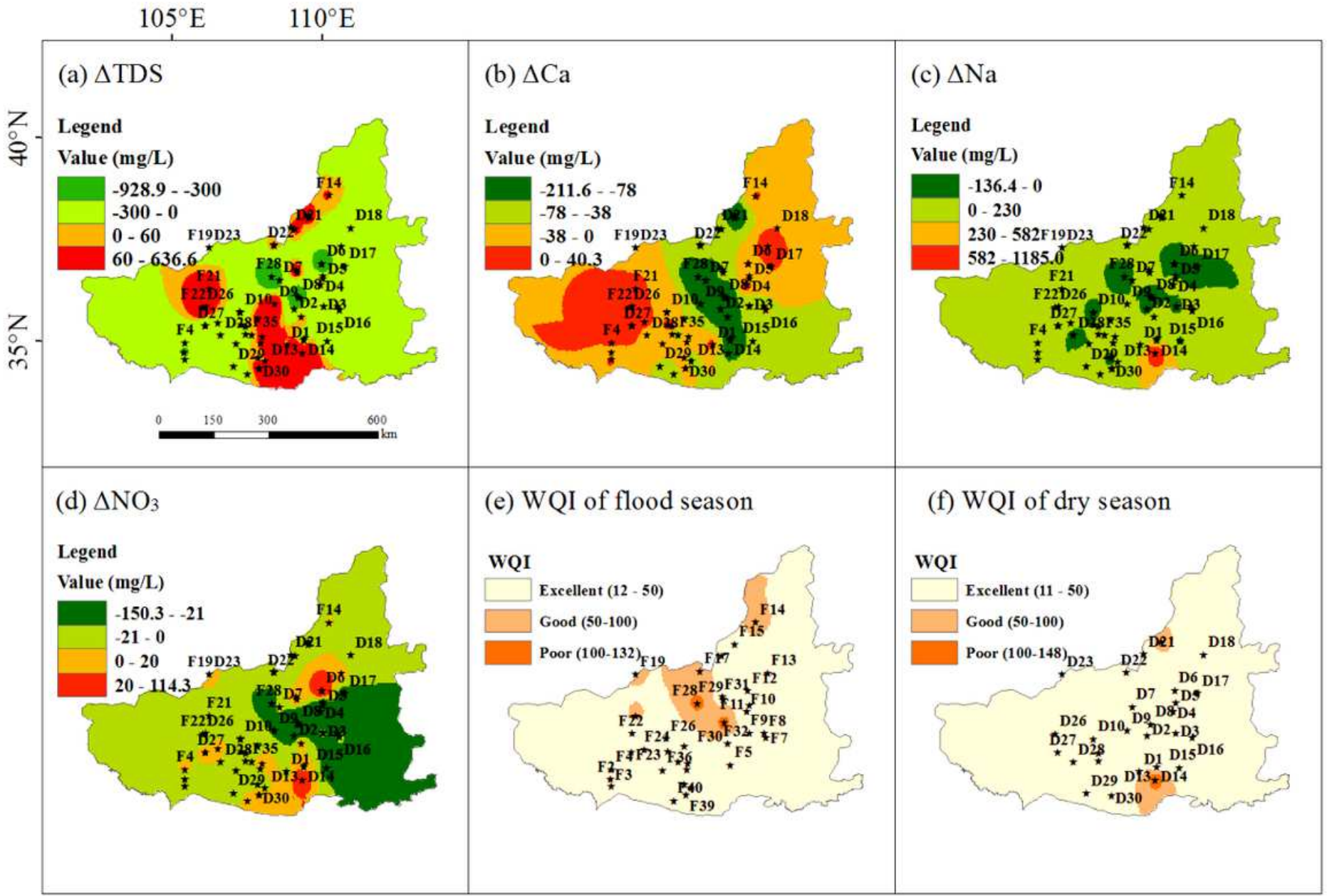


Figure 6

Spatial patterns in the seasonal difference of TDS (a), Ca2+ (b), Na+ (c), NO3- (d), and WQI in the flood season (e) and the dry season (f). Note: The designations employed and the presentation of the material on this map do not imply the expression of any opinion whatsoever on the part of Research Square concerning the legal status of any country, territory, city or area or of its authorities, or concerning the delimitation of its frontiers or boundaries. This map has been provided by the authors.
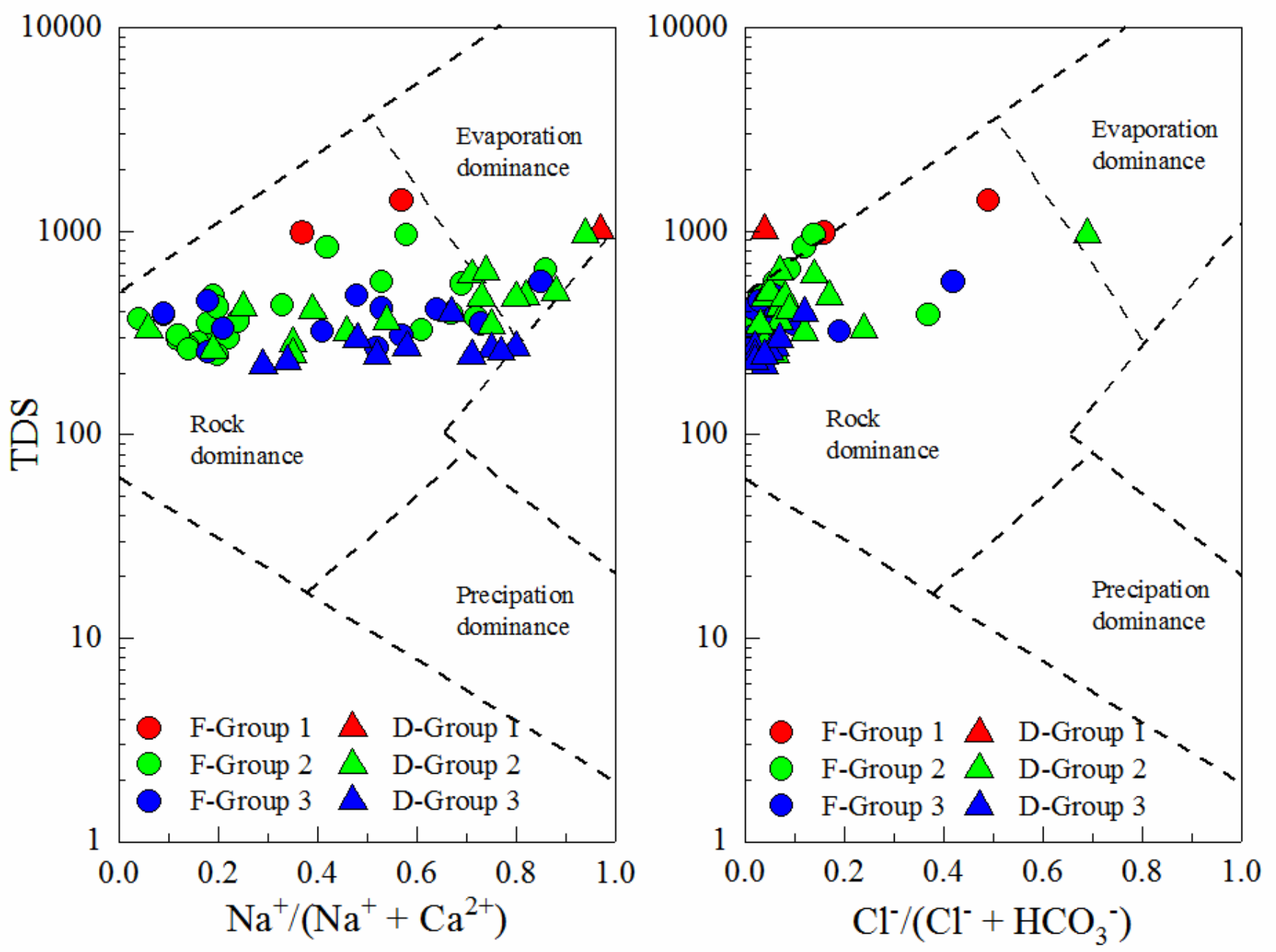

Figure 7

Scatterplots of (a) TDS versus $\mathrm{Na} /(\mathrm{Na}+\mathrm{Ca})$ and (b) TDS versus $\mathrm{Cl} /(\mathrm{Cl}+\mathrm{HCO})$ to illustrate the dominant processes that control dissolved solutes. 
(a)

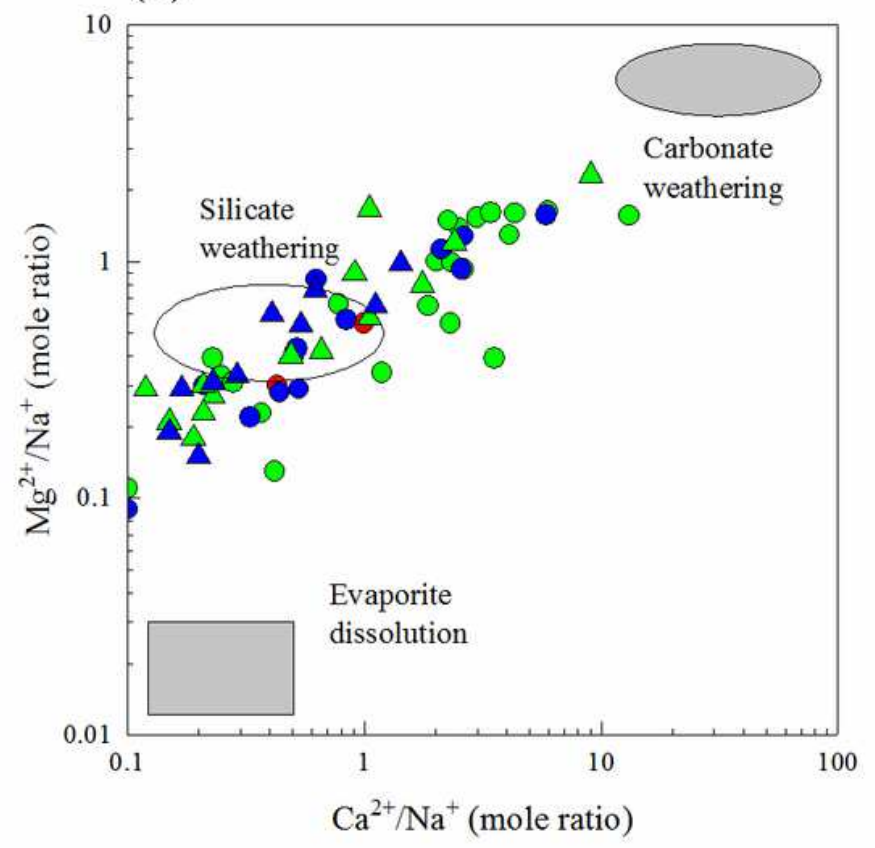

(b)

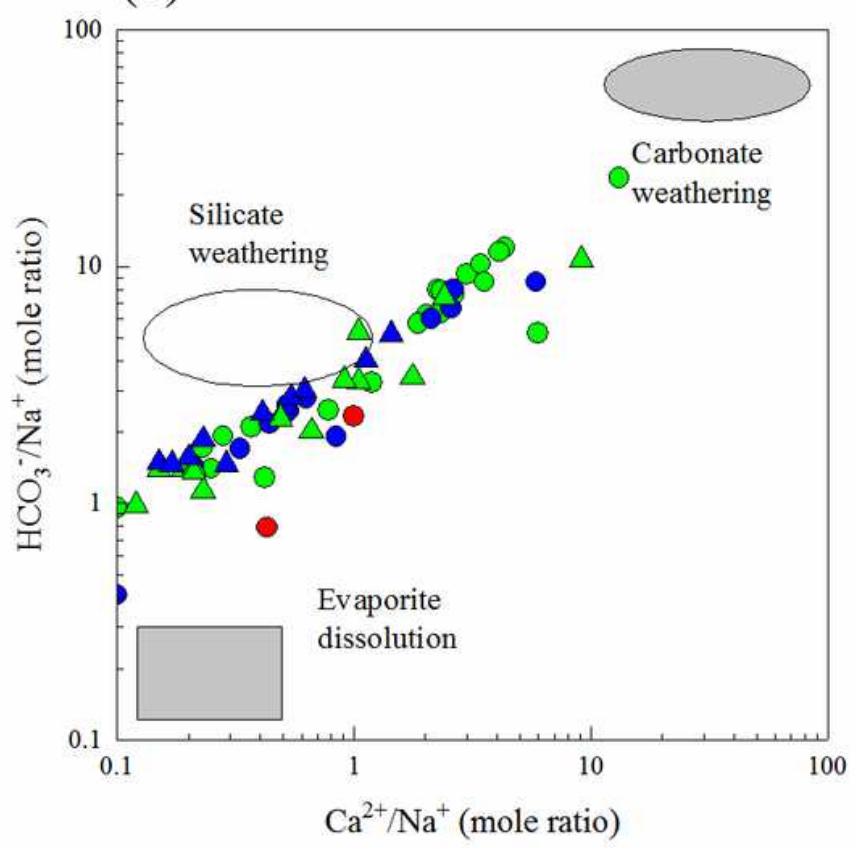

- F-Group $1 \Delta$ D-Group 1

- F-Group $2 \Delta$ D-Group 2

- F-Group $3 \Delta$ D-Group 3

\section{Figure 8}

Scatterplots of $\mathrm{Na}+-$ normalized $\mathrm{Ca} 2+$ versus $\mathrm{Mg} 2+/ \mathrm{Na}+(\mathrm{a})$ and $\mathrm{HCO}^{-}$(b) to investigate the processes that control groundwater chemistry. 
(a)

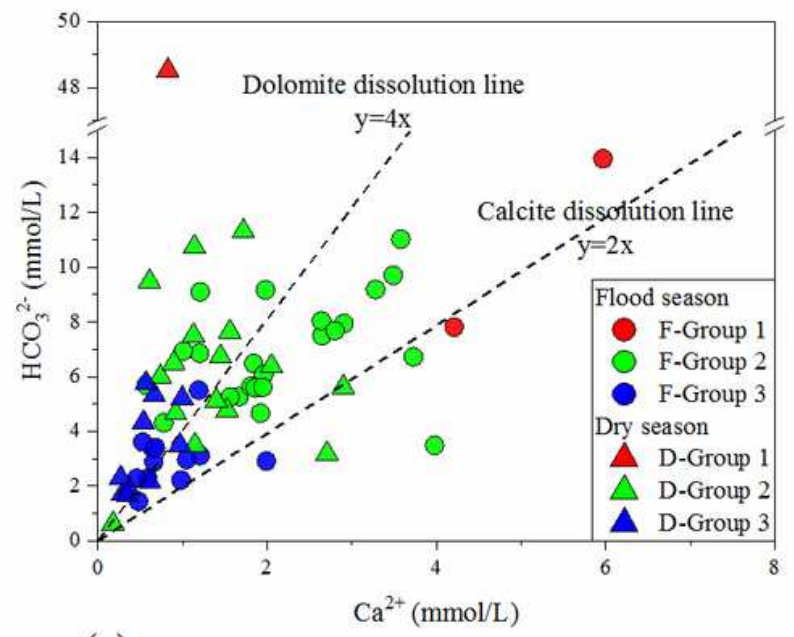

(c)

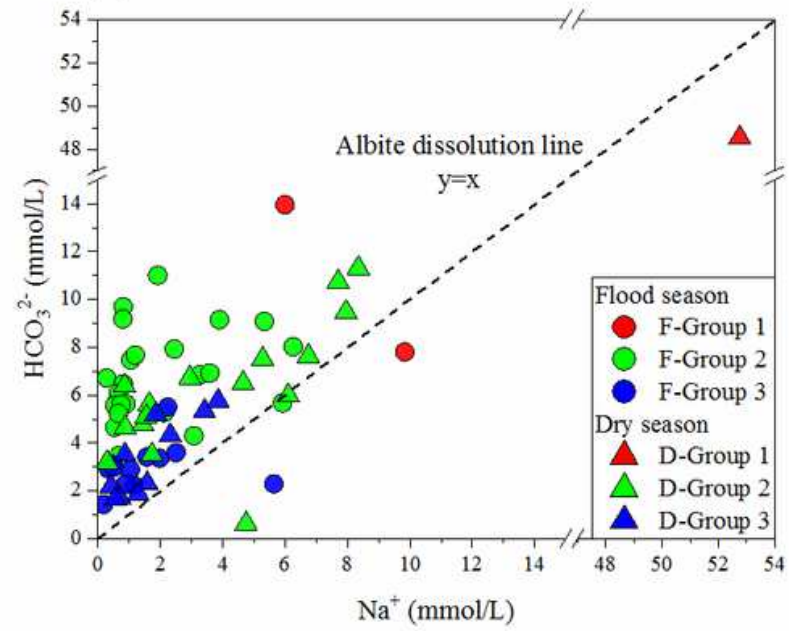

(b)

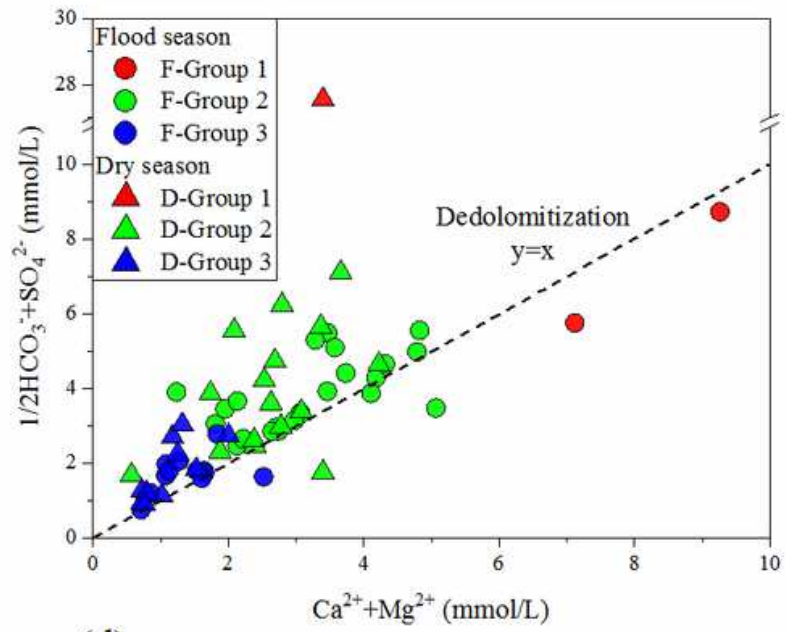

(d)

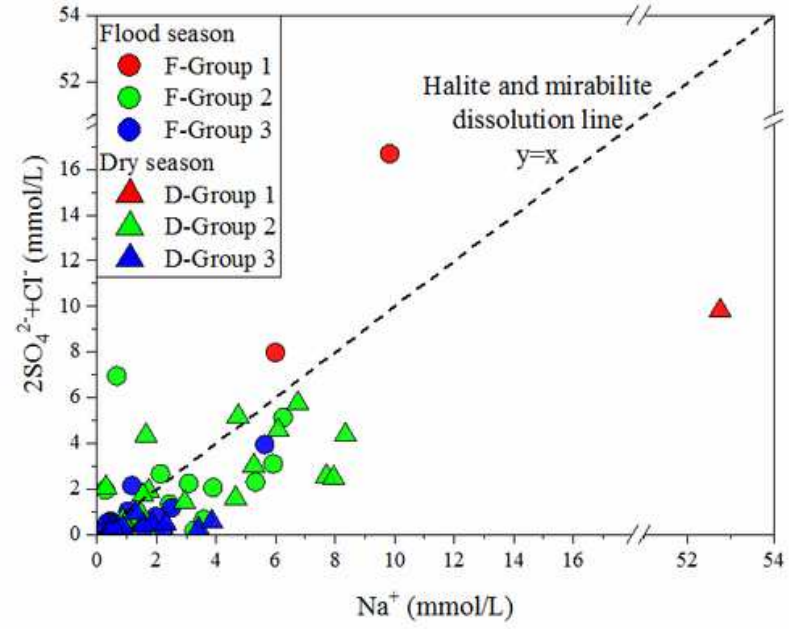

\section{Figure 9}

Bivariate diagrams of $\mathrm{HCO}$ - versus $\mathrm{Ca} 2+(\mathrm{a})$ to explore the contribution of carbonate to groundwater chemistry; $1 / 2 \mathrm{HCO} 3-+$ SO42- versus Ca2+ + Mg2+ (b) to examine gypsum dissolution; HCO3- versus Na+ (c) to investigate the silicate weathering; SO42- versus $\mathrm{Na}+(\mathrm{d})$ to verify the dissolution of evaporite. 